This is the author's final, peer-reviewed manuscript as accepted for publication. The publisher-formatted version may be available through the publisher's web site or your institution's library.

\title{
Evaluation of macrophage plasticity in brown and white adipose tissue
}

M. Teresa Ortega, Linglin Xie, Silvia Mora, Stephen K. Chapes

\section{How to cite this manuscript}

If you make reference to this version of the manuscript, use the following information:

Ortega, M. T., Xie, L., Mora, S., \& Chapes, S. K. (2011). Evaluation of macrophage plasticity in brown and white adipose tissue. Retrieved from http://krex.ksu.edu

\section{Published Version Information}

Citation: Ortega, M. T., Xie, L., Mora, S., \& Chapes, S. K. (2011). Evaluation of macrophage plasticity in brown and white adipose tissue. Cellular Immunology, 271(1), 124-133.

Copyright: () 2011 Elsevier Inc.

Digital Object Identifier (DOI): doi:10.1016/j.cellimm.2011.06.012

Publisher's Link:

http://www.sciencedirect.com/science/article/pii/S000887491100150X

This item was retrieved from the K-State Research Exchange (K-REx), the institutional repository of Kansas State University. K-REx is available at http://krex.ksu.edu 


\section{Elsevier Editorial System(tm) for Cellular Immunology Manuscript Draft}

Manuscript Number: CIMM-11-43R2

Title: Evaluation of macrophage plasticity in brown and white adipose tissue

Article Type: Regular Article

Keywords: macrophage, plasticity, adipocyte, adipose tissue, trafficking

Corresponding Author: Dr. Stephen Keith Chapes, Ph.D.

Corresponding Author's Institution: Kansas State University

First Author: M. Teresa Ortega, Ph.D.

Order of Authors: M. Teresa Ortega, Ph.D.; Linglin Xie, Ph.D.; Silvia Mora, Ph.D.; Stephen Keith Chapes, Ph.D.

Abstract: There are still questions about whether macrophage differentiation is predetermined or is induced in response to tissue microenvironments. C2D macrophage cells reside early in the macrophage lineage in vitro, but differentiate to a more mature phenotype after adoptive transfer to the peritoneal cavity (PEC-C2D). Since C2D macrophage cells also traffic to adipose tissue after adoptive transfer, we explored the impact of white adipose tissue (WAT), brown adipose tissue (BAT) and in vitro cultured adipocytes on C2D macrophage cells.

When PEC-C2D macrophage cells were cultured with preadipocytes the cells stretched out and CD11b and Mac-2 expression was lower compared to PEC-C2D macrophage cells placed in vitro alone. In contrast, PEC-C2D cells co-cultured with adipocytes maintained smaller, round morphology and more cells expressed Mac-2 compared to PEC-C2D co-cultured with preadipocytes. After intraperitoneal injection, C2D macrophage cells migrated into both WAT and BAT. A higher percentage of C2D macrophage cells isolated from WAT (WAT-C2D) expressed Ly-6C (33\%), CD11b (11\%), Mac-2 (11\%) and F4/80 (29\%) compared to C2D macrophage cells isolated from BAT (BAT-C2D). Overall, BAT-C2D macrophage cells had reduced expression of many cytokine, chemokine and receptor gene transcripts when compared to in vitro grown C2D macrophages, while WAT-C2D macrophage cells and PEC-C2D up-regulated many of these gene transcripts. These data suggest that the C2D macrophage phenotype can change rapidly and distinct phenotypes are induced by different microenvironments. 
1 Evaluation of macrophage plasticity in brown and white adipose tissue

4 M. Teresa Ortega ${ }^{1 \dagger}$, Linglin Xie ${ }^{1 \dagger}$, Silvia Mora $^{2}$, and Stephen K. Chapes ${ }^{1 *}$

$5 \quad{ }^{1}$ Division of Biology, Kansas State University, Manhattan, KS, 66506 and ${ }^{2}$ Department of

6 Cellular and Molecular Physiology, Institute of Translational Medicine, The University of

7 Liverpool, Crown Street, Liverpool L69 3BX, United Kingdom

$8 \uparrow$ Co-first authors

10 Running Title: Macrophage-adipose interactions

13 *Address correpondence to:

14 Stephen K. Chapes

15116 Ackert Hall

16 Kansas State University

17 Manhattan, KS 66506-4901

18 E mail:skcbiol@ksu.edu

19 Voice: 785-532-6795

20 Fax: 785-532-6653 


\section{ABSTRACT}

There are still questions about whether macrophage differentiation is predetermined or is

26 induced in response to tissue microenvironments. C2D macrophage cells reside early in the

27 macrophage lineage in vitro, but differentiate to a more mature phenotype after adoptive transfer

28 to the peritoneal cavity (PEC-C2D). Since C2D macrophage cells also traffic to adipose tissue

29 after adoptive transfer, we explored the impact of white adipose tissue (WAT), brown adipose

30 tissue (BAT) and in vitro cultured adipocytes on C2D macrophage cells.

31 When PEC-C2D macrophage cells were cultured with preadipocytes the cells stretched

32 out and CD11b and Mac-2 expression was lower compared to PEC-C2D macrophage cells

33 placed in vitro alone. In contrast, PEC-C2D cells co-cultured with adipocytes maintained

34 smaller, round morphology and more cells expressed Mac-2 compared to PEC-C2D co-cultured

35 with preadipocytes. After intraperitoneal injection, C2D macrophage cells migrated into both

36 WAT and BAT. A higher percentage of C2D macrophage cells isolated from WAT (WAT-

37 C2D) expressed Ly-6C (33\%), CD11b (11\%), Mac-2 (11\%) and F4/80 (29\%) compared to C2D

38 macrophage cells isolated from BAT (BAT-C2D). Overall, BAT-C2D macrophage cells had

39 reduced expression of many cytokine, chemokine and receptor gene transcripts when compared

40 to in vitro grown C2D macrophages, while WAT-C2D macrophage cells and PEC-C2D up-

41 regulated many of these gene transcripts. These data suggest that the $\mathrm{C} 2 \mathrm{D}$ macrophage

42 phenotype can change rapidly and distinct phenotypes are induced by different

43 microenvironments. 


\section{Introduction}

Macrophages are found throughout the body and serve as initiators and effectors of the

50 innate immune system [1-6]. Macrophages differentiate from bone marrow hematopoietic stem

51 cells through various stages including, macrophage-colony forming cells to monoblasts,

52 promonocytes and finally into monocytes [7,8]. Monocytes enter the bloodstream, where they

53 circulate before migrating into tissues. There they differentiate into tissue-specific macrophages

54 [9]. Macrophages are a heterogeneous group of cells which have different functions,

55 morphologies and phenotypic properties [7,9]. Heterogeneity is commonly associated with

56 macrophages as a consequence of the functions, organ sites and immune status of the host $[9,10]$.

57 However, there is controversy about macrophage adaptation to microenvironmental signals in

58 vivo [10-13]. Some think that since subpopulations of macrophages have either proinflammatory

59 (M1) or anti-inflammatory (M2) properties, there are predetermined fates for monocytes and

60 macrophages as opposed to the microenvironmental signaling leading to the macrophage

61 plasticity $[10,14]$.

62 C2D macrophage cells reside early in the macrophage lineage in vitro, but differentiate to

63 a more mature, phenotype after adoptive transfer to the peritoneal cavity (PEC-C2D) [15]. These

64 macrophage cells differentiate and traffic like primary macrophages and can provide insight into

65 macrophage function [16]. In particular, they can provide evidence about macrophage plasticity

66 in response to different microenvironments.

67 White adipose tissue (WAT) and brown adipose tissue (BAT) have distinct physiological

68 functions. WAT is an energy storage and endocrine organ [17,18]. In contrast, BAT functions

69 as an energy-dissipating organ through adaptive-thermogenesis [19]. These adipocyte depots

70 display different morphology, cellular characteristics, body localizations and function [19-24]. 
Previous studies have suggested that macrophage function varies considerably in

72 different fat depots [25]. Some have also suggested that macrophage plasticity is an artifact of in

73 vitro manipulations [10]. Given the controversy about macrophage adaptation to

74 microenvironmental signals in vivo [10-13] and the fact that little is known about BAT-

75 macrophage interactions, we investigated whether macrophage phenotype is predetermined or is 76 adaptable.

\section{Materials and methods}

\subsection{Mouse strains}

C57BL/6J (B6) mice were originally obtained from the Jackson Laboratory (Bar Harbor,

81 ME). Male and female, 8-16 week-old mice were bred in the rodent facility of the Division of

82 Biology at Kansas State University and used in these experiments. Mice were fed a normal

83 mouse chow diet (5001, PMI International, St. Louis, MO) and were allowed to feed Ad libitum.

84 All animal experiments were approved by the Institutional Animal Care and Use Committee.

\subsection{Antibodies and Reagents}

Collagenase (Type II), insulin from bovine pancreas, 3-Isobutyl-1-methylxanthine

88 (IBMX) and dexamethasone were obtained from Sigma-Aldrich Co. (St. Louis, MO).

89 Carboxyfluorescein diacetate, succinmidyl (CFDA-SE) ester was purchased from Molecular

90 probes (Eugene, OR). APC conjugated anti-CD11c, APC conjugated anti-F4/80, APC

91 conjugated anti-CD11b, ALEXA Fluor 647 conjugated anti-Mac2, and their isotype control

92 antibodies were purchased from eBioscience (San Diego, CA). Biotin conjugated anti-Ly-6C 
93 (ER-MP20) and its isotype control antibody were from BD Pharmingen (San Jose, CA). APC

94 conjugated Streptavidin was purchased from eBioscience (San Diego, CA).

\subsection{Cell lines and cell culture}

The C2D macrophage cell line was created as described by our group [26]. These cells

98 were derived from C2D mouse bone marrow and selected in the presence of macrophage colony

99 stimulating factor (M-CSF). These cells have the $\mathrm{MHCII}^{\prime-}$ and $\mathrm{Tlr} 4^{\mathrm{Lps}-\mathrm{n}}$ genotype and are

100 histocompatible with mice of the H-2 ${ }^{b}$ haplotype. C2D cells were grown in Dulbecco's

101 Modified Eagle's Medium with 4\% fetal bovine serum (DMEM $)$ supplemented with $0.3 \%$

102 Glutamax and 10\% Opti-MEM in 150-mm tissue culture plates.

103 3T3L1 adipocytes were obtained from the American Type Culture Collection (Manassas,

104 VA). Adipocytes were cultured and differentiated as described previously [27]. Briefly, 3T3L1

105 cell differentiation was induced by culturing cells in DMEM containing 10\% FBS (DMEM 10$), 1$

$106 \mu \mathrm{M}$ dexamethasone, $1.7 \mu \mathrm{M}$ insulin and $0.5 \mathrm{mM}$ IBMX for 4 days. On the fourth day, the

107 3T3L1 cells were cultured in $\mathrm{DMEM}_{10}$ with $1.7 \mu \mathrm{M}$ insulin. On day 8, 3T3L1 cells were

108 maintained in DMEM $_{10}$. Undifferentiated preadipocytes and adipocytes differentiated for 6-8

109 days were used in the experiments. 3T3L1 cells $\left(1 \times 10^{6}\right.$ cells $)$ were directly co-cultured with

$1101 \times 10^{6} \mathrm{C} 2 \mathrm{D}$ cells grown exclusively in vitro or $1 \times 10^{6}$ cells adoptively transferred C2D

111 macrophage cells isolated from the peritoneal cavity (PEC-C2D).

112 Bone marrow derived macrophages (BM-Mo) were differentiated from B6 mouse bone

113 marrow cells isolated from the femora, tibiae, and humeri. Briefly, the bones were recovered and

114 cleaned of all non-osseous tissue. The marrow cavity was flushed with a sterile PBS solution.

115 The red blood cells were lysed by incubating in ammonium chloride lysis buffer $\left(0.15 \mathrm{M} \mathrm{NH}_{4} \mathrm{Cl}\right.$, 
$11610 \mathrm{mM} \mathrm{KHCO}_{3}$, and $0.1 \mathrm{mM} \mathrm{Na} 2$ EDTA, $\mathrm{pH}$ 7.3) for $5 \mathrm{~min}$ in ice. Cells were centrifuged $(300 \mathrm{x}$

$117 \mathrm{~g}, 5 \mathrm{~min}$ ) and washed two times with $\mathrm{DMEM}_{2}$. Bone marrow cells were seeded and incubated in

118 M-CSF medium (DMEM 10 , OPTI-MEM, 0.01 M HEPES, 50 ng/ml gentamycin, $1.5 \mathrm{ng} / \mathrm{ml}$

119 rMCSF-1) for 7 days at $37{ }^{\circ} \mathrm{C}, 8 \% \mathrm{CO}_{2}$. BM-Mo were indirectly co-cultured with collagenase-

120 digested white adipose tissue (WAT) gonadal fat pads or collagenase- digested BAT perispleen

121 or interscapular fat pads as described below.

122

1232.4 Adoptive transfer of labeled cells

$124 \quad \mathrm{C} 2 \mathrm{D}$ cells were suspended in sterile, pre-warmed $\left(37^{\circ} \mathrm{C}\right)$ phosphate buffered saline (PBS;

$125137 \mathrm{mM} \mathrm{NaCl}, 10 \mathrm{mM}$ Phosphate, $2.7 \mathrm{mM} \mathrm{KCl}, \mathrm{pH} 7.4)$ at a concentration of $1.5 \times 10^{6}$ cells per $126 \mathrm{ml}$, further stained with CFDA-SE according to the manufacturer's protocol. Briefly, C2D cells 127 were incubated with $22 \mu \mathrm{M}$ of CFDA-SE solution at $37^{\circ} \mathrm{C}$ for 15 minutes. After centrifugation 128 at $370 \mathrm{x}$ g for 10 minutes, cell pellets were suspended in pre-warmed $\mathrm{PBS}$ and incubated in $37^{\circ} \mathrm{C}$ 129 for an additional 20 minutes. Cells were then washed twice in PBS, and suspended at a 130 concentration of $4 \times 10^{7}$ cells per $\mathrm{ml}$ in PBS. One and one-half $\mathrm{ml}$ of the cell suspension of 131 CFDA-SE labeled C2D or normal C2D cells was injected intraperitoneally (i.p.) per mouse.

\subsection{Peritoneal cell extraction and fat tissue isolation}

PEC-C2D macrophage cells were obtained from B6 mice by peritoneal lavage 36 hours

135 after intraperitoneal injection of $4 \times 10^{7}$ of C2D macrophage cells labeled with CFDA-SE. The 136 peritoneal exudate red blood cells were lysed as described in section 2.3. One-half of the cells 137 were treated with $1 \mathrm{mg} / \mathrm{ml}$ collagenase type II at $37^{\circ} \mathrm{C}$ with shaking $(60 \mathrm{rpm})$ for 40 minutes. 
138 Control or collagenase-treated cells were washed three times with PBS and $3 \times 10^{6}$ cells were 139 plated into 150-mm cell culture plates and incubated in $\mathrm{DMEM}_{4}$ for 16 hours. Isolation of adipocytes and CFDA-SE labeled C2D macrophage cells was performed as

141 previously described $[15,16]$. Adipocytes were isolated from both mouse gonadal fat pads

142 (depots connected to the uterus and ovaries in females and the epididymis and testes in males) 143 and perispleen adipose tissues by collagenase digestion [28,29]. We confirmed BAT origin by 144 quantitating the mRNA of PRDM16 by qRT-PCR [30] and/or UCP-1 [31] in tissues collected 145 from perispleen and interscapular isolates (data not shown). Gonadal fat pads weighed an 146 average of $268 \mathrm{mg}$ while perispleen fat averaged $98 \mathrm{mg}$. Interscapular fat pads weighed an 147 average of $61 \mathrm{mg}$. The fat pads were minced and incubated for $10 \mathrm{~min}$ in pre-warmed $\left(37^{\circ} \mathrm{C}\right)$ 148 Krebs-Ringer phosphate (KRP) buffer (12.5 mM HEPES, $120 \mathrm{mM} \mathrm{NaCl}, 6 \mathrm{mM} \mathrm{KCl}, 1.2 \mathrm{mM}$ $149 \mathrm{MgSO}_{4}, 1 \mathrm{mM} \mathrm{CaCl} 2,0.6 \mathrm{mM} \mathrm{Na}_{2} \mathrm{HPO}_{4}, 0.4 \mathrm{mM} \mathrm{Na}_{2} \mathrm{H}_{2} \mathrm{PO}_{4}, 2.5 \mathrm{mM} \mathrm{D}$-glucose, and $2 \%$ 150 bovine serum albumin, $\mathrm{pH}$ 7.4), thereafter the samples were incubated with Type II collagenase $151(1 \mathrm{mg} / \mathrm{ml})$ for $40 \mathrm{~min}$ at $37^{\circ} \mathrm{C}$ with constant shaking at $60 \mathrm{rpm}$. The WAT or BAT cells were 152 passed through a $100 \mu \mathrm{m}$ cell strainer; cells were then centrifuged at $370 \mathrm{x}$ g for 1 minute and 153 washed with Krebs Ringer buffer twice. Additionally, the adipocytes isolated from the paired 154 gonadal fat pads were separated into 2 major fractions. The floating upper layer was primarily 155 white adipocytes and the pelleted fraction was a mixture of stromal-vascular fraction (SVF) cells 156 containing macrophages. Both cell fractions were collected and washed twice with KRP buffer. 157 WAT and BAT cells were scored for numbers and viability on a hemacytometer using 158 trypan blue exclusion. Viability was $91 \pm 0 \%, 81 \pm 3 \%$ and $87 \pm 0 \%$ for PEC, BAT and SVF cells, 159 respectively, after isolation and collagenase treatment. In collagenase-digested samples, we 160 isolated an average of $1.3 \times 10^{5} \mathrm{C} 2 \mathrm{D}$ macrophage cells per mouse from gonadal WAT and $8.9 \times$ 
$16110^{4} \mathrm{C} 2 \mathrm{D}$ macrophage cells from perispleen BAT or $3.5 \times 10^{4} \mathrm{C} 2 \mathrm{D}$ macrophage cells from

162 interscapular BAT. $1 \times 10^{5}$ cells were pelleted onto a cytospin slide for differential staining. A

163 mixture of white adipocytes (upper layer) and $\mathrm{SVF}$ cells was co-incubated at $37^{\circ} \mathrm{C}$ in $\mathrm{DMEM}_{10}$,

164 for 16 hours at a concentration of $1 \times 10^{5}$ cells $/ \mathrm{ml}$ in a $150-\mathrm{mm}$ culture dish. The adipocytes

165 remained dispersed in the medium and the SVF cells attached to the $150-\mathrm{mm}$ culture plate. The

166 adipocytes isolated from perispleen adipose were collected from the cell pellets and washed

167 twice with KRP buffer. Cells isolated from perispleen BAT $\left(3 \times 10^{6}\right)$ were cultured at $37^{\circ} \mathrm{C}$ in

168 DMEM $_{10}$ in a $150-\mathrm{mm}$ culture plate for 16 hours.

169

1702.6 Flow cytometry analysis of C2D macrophage cells

171 Cell sorting was based on C2D macrophage cell CFDA-SE fluorescence, with the lowest

$17210 \%$ of the positive cells not selected. Briefly, cell sorting was performed with either a

173 FACSVantage SE cell sorter (Becton Dickson. Rockville, MD) or a MoFlo XDP Sterile Cell

174 Sorter (Beckman Coulter), using specimen optimization and calibration techniques according to

175 the manufacture's recommendations. Cells were sorted at a rate of 15,000 cells per second and

176 approximately $1 \times 10^{6}$ viable (trypan blue exclusion), positive cells per group were collected on

177 ice and centrifuged at $350 \mathrm{xg}$ for $5 \mathrm{~min}$ at $4^{\circ} \mathrm{C}$ for PCR Array or qRT-PCR analysis.

178 We found a loss of cell surface markers following collagenase treatment. For example,

179 Mac-2 was down regulated over 50\% after a 40 minute collagenase treatment based on control

180 PEC-C2D (data not shown). However, we were also concerned that this incubation would also

181 influence the cells. Therefore, we also evaluated the changes in TNF gene expression over time

182 after the PEC-C2D cells were cultured in vitro. We found C2D macrophage gene expression

183 was reduced some but was still positive for at least 24 hrs (data not shown). Therefore, we felt a 
184 reasonable approach to phenotype the cell surface molecules of the recovered C2D macrophage

185 cells from PEC, BAT and WAT would be to allow the cells to recover in vitro for 16 hours at

$18637^{\circ} \mathrm{C}$ in medium. Therefore, control or collagenase-treated C2D macrophage cells isolated from

187 the peritoneal cavity (PEC-C2D), WAT and BAT were resuspended in $\mathrm{DMEM}_{4}$ and incubated

188 for 16 hours prior to labeling cell surface proteins and assessment by flow cytometry.

189 Cells were transferred to wells of 96-well, round-bottom plates and they were blocked 190 with PBS-goat serum $(50: 50 ; 50 \mu \mathrm{l})$ at $4{ }^{\circ} \mathrm{C}$ for 0.5 hour. Subsequently, macrophage cell surface

191 proteins were identified by direct labeling. Briefly, blocked cells were incubated with the isotype 192 or specific antibody diluted in Hank's Buffered Salt Solution (HBSS; 0.137 M NaCl, 5.4 mM

$193 \mathrm{KCl}, 0.25 \mathrm{mM} \mathrm{Na}_{2} \mathrm{HPO}_{4}, 0.44 \mathrm{mM} \mathrm{KH}_{2} \mathrm{PO}_{4}, 1.3 \mathrm{mM} \mathrm{CaCl}_{2}, 1.0 \mathrm{mM} \mathrm{MgSO}$, $4.2 \mathrm{mM} \mathrm{NaHCO}_{3}$ )

194 for 1 hour in the dark at $4^{\circ} \mathrm{C}$. After two washes with HBSS, cells were fixed in $1 \%$ formalin.

195 Labeled cell surface proteins were assessed by flow cytometry. We gated on live, CFDA-SE-

196 positive or CFDA-SE negative cells, subsequently we assayed for the presence or absence of the 197 selected cell surface markers.

1992.7 Real time quantitative RT-PCR analysis

200 RNA was obtained by suspending the pelleted cells in $1 \mathrm{ml}$ of TriReagent (Molecular

201 Research Center). The solution was transferred to $2.0 \mathrm{ml}$ Heavy Phase Lock Gel tubes (5

202 Prime). $200 \mu \mathrm{l}$ of chloroform was added and the mixture was shaken for 15 seconds. The

203 samples were then centrifuged at $12,000 \mathrm{x}$ g for 10 minutes at $4{ }^{\circ} \mathrm{C}$ and the aqueous phase was

204 transferred to clean $1.5 \mathrm{ml}$ tubes. $500 \mu \mathrm{l}$ of isopropanol was added and RNA was precipitated at $205-20^{\circ} \mathrm{C}$ for 24 hours. Samples were subsequently centrifuged at $12,000 \mathrm{x} g$ for 10 minutes. The 206 RNA pellet was washed with $1 \mathrm{ml}$ of $70 \%$ ethanol and samples were centrifuged at $7.4 \mathrm{x} \mathrm{g}$ for 5 
207 minutes. The 70\% ethanol was decanted from the pellet; the pellet was allowed to slightly air 208 dry and was resuspended in $50 \mu 1$ of nuclease-free water. RNA samples were purified and 209 DNAse treated with EZRNA total RNA kit (Omega Bio-Tek, Inc.). One step qRT-PCR was 210 performed using the SuperScript III Platinum SYBR Green kit (Invitrogen; Carlsbad, CA)

211 according to the manufacturer's protocol. Primers were designed with the PrimerQuest software

212 (IDT; http://www.idtdna.com) using sequence data from NCBI sequence database as following:

213 TNF- $\left.\alpha \mathrm{NM} \_013693\right)$ forward 5'-tctcatgcaccaccatcaaggact and reverse 5'-

214 tgaccactctccctttgcagaact; IL-6 NM_031168.1) forward 5'-tctcatgcaccaccatcaaggact and reverse

215 5'- tgaccactctccetttgcagaact; ILI- $\beta$ NM_008361) forward 5'-aagggctgcttccaaacctttgac and reverse

216 5'-atactgectgcetgaagctcttgt; Arg-1(NM_007482) forward 5'-tggctttaacettggcttgcttcg and reverse

217 5'-catgtggcgcattcacagtcactt; Ym-1 (M94584) forward 5'-caccatggccaagctcattcttgt and reverse 5'-

218 tattggcctgtccttagcccaact; Fizz-1(NM_020509.3) forward 5'-actgcetgtgcttactcgttgact and reverse

219 5'-aaagctgggttctccacctcttca; Prdm16 (BC059838) forward 5'-tcatcccaggagagctgcatcaaa and

220 reverse 5'-atcacaggaacacgctacacggat; Ucp-1 (NM009463.3) forward 5'-ttgagctgctccacagcgcc

221 and reverse 5' -gttgcctgatgcgggcacga; $\beta$-actin (NM_007393) forward 5'-

222 tgtgatggtgggaatgggtcagaa and reverse 5 '-tgtggtgccagatcttctccatgt. The qRT-PCRs were

223 performed in a Cepheid SmartCycler System (Sunnyvale, CA). Fold increase in transcript

224 expression was calculated: E (gene of interest) ${ }^{\Delta c t \text { target }} / \mathrm{E}$ ( housekeeping) ${ }^{\Delta c t \text { housekeeping }}$ where $\mathrm{E}$

225 (efficiency) $=10^{(-1 / \text { slope })}$ as was previously described [32].

2262.8 PCR array analysis

227 Expression analysis of 84 cytokines, chemokines and corresponding receptor genes

228 involved in inflammatory responses was performed with the mouse inflammatory cytokines and 229 receptors $\mathrm{RT}^{2}$ profiler $^{\mathrm{TM}}$ PCR array system (SuperArray Bioscience Corporation, Frederick, 
230 MD). $1.2 \mu \mathrm{g}$ of total RNA was obtained from CFDA SE labeled C2D cells sorted from the PEC,

231 WAT, and BAT of C57BL/6J mice ( $\mathrm{n}=2$ pooled RNA samples, 4 mice per pooled sample).

232 Genomic DNA was digested with RNAse-free DNAase, followed by first strand cDNA synthesis

233 and then quantitative mRNA analysis according to manufacturer's protocol. The quantitative

234 real-time PCR array was done on a BioRad iCycler (BioRad Laboratory, Hercules, CA)

235 performed with the $\mathrm{RT}^{2}$ SYBR Green/Fluorescein qPCR Master Mix (SuperArray Bioscience

236 Corporation, Frederick, MD). Expression of mRNA for each gene was normalized to the

237 expression of $\beta$-actin and compared to the data obtained with the negative control (RNA from

238 cultured C2D cells) according to the $\Delta \Delta \mathrm{Ct}$ method [32].

\subsection{Immunofluorescence and image analysis}

Gonadal fat pads and perispleen adipose tissue were washed in Krebs-Ringer phosphate

242 (KRP) buffer fixed in 10\% formalin/PBS and were cut into 50- $\mu \mathrm{m}$-thick slices using a TC-2

243 tissue sectioner (Sorvall Instruments). Tissue slices were mounted onto glass slides, and

244 differential contrast interference (DIC) images of tissue and CFDA SE-labeled C2D macrophage

245 cells were observed on a model LSM 5 Pascal Zeiss laser scanning confocal microscope. Tissues

246 were visualized with 20X/0.5 and 40X/0.75 Plan Neofluor objectives with DIC. CFDA SE-

247 labeled C2D macrophage cells were visualized using the 488-nm line of an argon ion gas laser

248 (excitation of CFDA SE), an FT 488 primary dichroic beam splitter, a FT 545 secondary dichroic

249 beam slitter, a 505-nm to 530-nm-bandpass filter, a photomultiplier tube, and LSM5 Pa software,

250 version 3.2 SP2. The number of CFDA SE-labeled macrophages per square micrometer of area

251 of adipose tissue was determined using ImageJ v1.37 (NIH). Images were then imported to

252 Adobe Photoshop (Adobe Systems, Inc.) for figure processing. 
$254 \quad 2.10$ Statistical analysis.

255 Flow cytometry data, cell distribution data and qRT-PCR data were presented as the 256 mean \pm standard error of mean $(\mathrm{SEM})$ of independent experiments $(\mathrm{n}=3$ samples, 3 mice per 257 sample unless stated otherwise in the Figure legend). Differences in mean were determined 258 using Student's $t$ test (paired, two-tailed) or were determined using the Mann-Whitney rank-sum

259 test. Differences in cell distribution were assessed using the Chi-Square $\left(\chi^{2}\right)$ test. All tests were 260 calculated using the StatMost statistical package (Data XIOM, Los Angeles, CA). Differences 261 were considered significantly different when $P<0.05$. To assess differences in the samples 262 assayed in the PCR Arrays the mean Ct values between macrophage isolates were compared 263 using minimum significant difference (MSD) [33]. Any difference between means greater than 264 or equal to the MSD was considered to be a statistically different, while differences less than the 265 minimum significant difference were considered to be non-significant. An MSD was calculated 266 using the following equation: $\mathrm{MSD}=2 \times\left(\mathrm{s} \_\right.$pool $) \times(\sqrt{ }(1 / \mathrm{n} 1+1 / \mathrm{n} 2))$, where s pool is the standard 267 deviation pooled across all genes and all groups, $\mathrm{n} 1$ and $\mathrm{n} 2$ are the numbers of replicates for the 268 two treatments. In this study, $\mathrm{n} 1=\mathrm{n} 2=2$, and the pooled standard deviation was equal to 1.61 and 269 the MSD was equal to 3.22.

271 3. Results

2723.1 Morphological and phenotypic changes of C2D macrophage cells in response to adipocytes 273 in vitro

274 To determine how different tissue environments impact macrophage phenotypes, we 275 investigated macrophage responses to preadipocytes and adipocytes. In our experiments we used 
276 the C2D macrophage cell line and 3T3L1 cells before or after, differentiation into adipocytes.

277 We previously established the specific macrophage phenotype expressed by C2D cells after they 278 were injected i.p. (PEC-C2D) or before they respond to other microenvironments $[15,16,26]$. In 279 order to visualize and identify the C2D macrophages, C2D cells were labeled with CFDA-SE 280 prior to their injection into the animals or their co-culture with (3T3L1) preadipocyte/adipocyte 281 cells in vitro for two days. Subsequently, these cells were recovered and analyzed by

282 fluorescence-activated cell sorting. Cells from peritoneal lavages, BAT and SVF cells from 283 WAT were sorted by FACS analysis as described in Figure 1. C2D cells grown in vitro (Figure 284 1A, region 1) and C2D CFDA-SE cells (Figure 1B, region 2) were used as negative and positive 285 controls for gating, respectively, and for sorting C2D CFDA-SE positive cells from mixed cell 286 samples such as C2D CFDA-SE macrophages co-cultured with 3T3L1 adipocytes (Figure 1C). In comparison to the larger stretched morphology of C2D macrophage cells grown in 288 vitro (Figure 2A, panels a and d), the PEC-C2D macrophage cells were round after cell isolation 289 (Figure 2B, panels a and d). When C2D or PEC-C2D macrophage cells were cultured with 290 preadipocytes, the cells stretched out (Figure 2A and 2B, panels b and e). In contrast, when C2D 291 macrophage cells or PEC-C2D cells were co-cultured with differentiated 3T3L1 adipocytes, we 292 found that the cells maintained a mostly smaller, round morphology (Figure 2A and 2B, panels c 293 and f), suggesting that differentiated 3T3L1 adipocytes inhibit normal adherence and stretching 294 of the C2D macrophage cells.

295 The morphological differences in C2D and PEC-C2D macrophage cells co-cultured with 296 adipocytes were accompanied by changes in cell phenotype defined by cell surface molecules 297 detected using flow cytometry. In vitro, $15 \%$ of the C2D macrophage cells expressed Mac-2 but 298 not CD11b; indicative of an immature macrophage phenotype [15]. C2D macrophage cells 
acquire a more differentiated phenotype after adoptive transfer in vivo with high levels of

300 macrophage-specific molecules CD11b, Mac2, F4/80, cfms and low levels of CD11c, and Gr-1

301 (Ly6G) $[15,16]$. We observed no change in the numbers of cells that expressed either of the cell

302 surface markers on C2D macrophage cells co-cultured with pre-adipocytes compared to C2D

303 macrophage cells cultured alone (Figure 3A). However, we observed a statistically significant

$304 \quad(P<0.05)$ increase in the number of C2D macrophages that expressed CD11b when co-cultured

305 with 3T3L1 adipocytes (Figure 3A). For PEC-C2D macrophage cells, their maturation in the

306 peritoneal cavity is accompanied by an increase in the number of cells that express CD11b

307 [15,16]. Significantly more PEC-C2D macrophage cells co-cultured in vitro with adipocytes

308 expressed Mac-2 than PEC-C2D macrophage cells cultured alone or with preadipocytes (Figure

$3093 \mathrm{~B}, P<0.05)$. We observed a significant decrease $(P<0.05)$ in the number of PEC-C2D

310 macrophage cells expressing CD11b and Mac-2 when incubated with preadipocytes (Figure 3B).

3123.2 Assessment of C2D macrophage cells after trafficking into WAT and BAT

313 We previously found that C2D macrophage cells could be isolated from gonadal WAT

314 [15]. However, macrophage trafficking to BAT has not been well characterized. We used

315 confocal microscopy to visualize and count C2D macrophages in WAT and BAT. We counted

316 an average of $97 \mathrm{C} 2 \mathrm{D}$ macrophages $/ \mathrm{mm}^{2}$ in BAT compared to $146 \mathrm{C} 2 \mathrm{D}$ macrophages $/ \mathrm{mm}^{2}$ in

317 WAT ( $P>0.05$, $\mathrm{T}$ test, $\mathrm{n} \geq 9$ fields scored per tissue; Figure $2 \mathrm{C})$. We also assessed if $\mathrm{C} 2 \mathrm{D}$

318 macrophage immigration to WAT and BAT induced inflammation. We did differential staining

319 of white blood cells isolated from the adipose tissue $36 \mathrm{hrs}$ after i.p. injection of C2D

320 macrophage cells. This survey revealed distinct cell distributions. The white cell distribution in

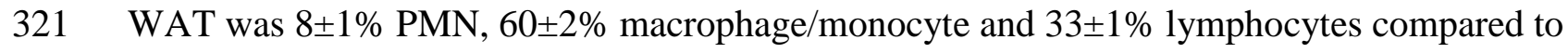


$3223 \pm 2 \%$ PMN, $79 \pm 2 \%$ macrophage/monocytes and $18 \pm 1 \%$ lymphocytes in BAT $\left(P<0.01 ; \chi^{2}\right.$ test $)$.

323 We also assessed C2D macrophage cell localization within WAT and BAT. WAT-C2D

324 appeared between adipocytes and some appeared to spread around the adipose cells (Figure 2C,

325 panels a, c, e). In contrast, BAT-C2D appeared only between adipocytes and generally had a

326 round appearance (Figure 2C, panels b, d, f).

327 To determine if the C2D macrophage cells isolated from BAT and WAT maintained the 328 same phenotype they expressed in the peritoneum or if they responded to the different tissue 329 environments, we compared BAT-C2D and WAT-C2D for the expression of Ly-6C, Mac-2,

$330 \mathrm{CD} 11 \mathrm{~b}$ and F4/80. Cells were labeled with CFDA and the CFDA-SE positive cells were

331 assessed (Figure 4A). We observed that 33\% of the WAT-C2D expressed Ly-6C, while there

332 were very few Ly6C-positive (<1\%) BAT-C2D. A significantly higher number of WAT-C2D

333 macrophage cells expressed $(P<0.05)$ Mac-2 compared to BAT-C2D macrophage cells. We

334 observed over 30\% of the WAT-C2D macrophage cells expressed F4/80, but almost no BAT-

335 C2D expressed F4/80 (Figure 4A). Significantly more WAT-C2D cells expressed CD11b than

336 BAT-C2D (Figure 4A). When we compared C2D macrophage phenotype to the phenotype of

337 the recipients' macrophages, we observed that a higher percentage of WAT-C2D cells expressed

338 F4/80 compared to the recipient's macrophages (CFDA negative cells; Figure 4B). We detected

339 no significant differences in the \% positive cells that expressed Ly-6C, Mac-2 or CD11b when

340 we compared WAT-C2D and recipient macrophages (Figure 4B).

341 To further characterize the impact of the adipose microenvironment on recently migrated

342 macrophages, we measured transcript levels in C2D macrophages that were isolated and sorted

343 from the peritoneal cavity, WAT or BAT. We measured the expression of an array of

344 inflammatory chemokines and cytokines and their receptor genes by quantitative PCR. As 
345 shown in Figure 5, the overall expression of chemokine, cytokine and receptor genes was

346 dramatically down-regulated in BAT-C2D cells relative to the gene expression of C2D cells

347 maintained in vitro, compared to those of PEC-C2D and/or sorted WAT-C2D cells. When

348 WAT-C2D cells were compared to PEC-C2D macrophage cells, transcript levels for several

349 chemokines were lower (Figure 5A). These included MIP-3b/CCL19 (3 vs. 9 fold), NAP-

350 3/CXCL1 (-0.5 vs. 5 fold), CCL11 (1 vs. 6 fold), CXCL5 (2 vs. 4 fold), CXCL9 (3 vs. 7) and

351 CXCL12 (4 vs. 12 fold). MIP-1a/CCL3 and MCP-5/CCL12 were also down-regulated in PEC-

352 C2D compared to C2D macrophages grown in vitro.

353 Interestingly we found that two cytokines receptor genes had higher transcript levels in

354 PEC-C2D macrophage cells compared to WAT-C2D macrophage cells; CD121a/IL 1r1 (8 vs. 2

355 fold) and CD130/IL6st (6 vs. 3 fold). Additionally, C3 (5 vs.1 fold) had higher expression in

356 PEC-C2D cells compared to WAT C2D cells (Figure 5E).

357 3.3 Macrophages gene expression in response to WAT and BAT in vitro

358 C2D macrophage cells exhibited distinct phenotypes in response to WAT or BAT

359 adipose environments. Therefore, to confirm that C2D macrophage behavior reflected that of

360 primary macrophages, we indirectly co-cultured BM-Mo in transwell plates (top) with

361 collagenase-digested WAT and BAT (bottom). RNA from the BM-Mo was isolated and the

362 transcript levels of $T N F-\alpha, I L-6, I L-1 \beta$, Arg-1, Ym-1 and Fizz-1 were assessed using qRT-PCR

363 (Table 1). WAT incubated BM-Mo macrophages had higher TNF- $\alpha$ and $I L-6$ transcript levels

364 than BAT-BM Mo (Table 1). This would be consistent with the observations seen with C2D

365 macrophages. In contrast, there were no differences in $I L-1 \beta$ or the anti inflammatory genes

366 Arg-1, Ym-1 and Fizz-1 between BM-Mo inoculated in WAT or BAT (Table 1). 


\section{Discussion}

Adipose tissue contains a heterogeneous array of cells including preadipocytes and

370 adipocytes along with resident and inflammatory macrophages constituting up to 40 percent of

371 the cell population [34]. Additionally, the trafficking of C2D macrophage cells to both WAT

372 and BAT provided a unique opportunity to determine the impact of these distinct adipose

373 environments on recently immigrating macrophages and how different microenvironments affect

374 macrophage plasticity. We used the C2D macrophage cell line to investigate this question. This

375 is a powerful model because the cells are phenotypically defined both in vitro and in vivo and the

376 phenotypic change of the C2D macrophages in response to WAT or BAT paralleled the in vitro

377 response of primary macrophages $\{$ Table 1; also see reference [35] $\}$. Therefore, by knowing the

378 characteristics of the C2D macrophages before and after exposure to the different adipose tissues

379 we know exactly what changes are due to their immediate exposure to different

380 microenvironments. Indeed, the finding that preadipocytes allowed C2D macrophage cells to

381 spread regardless of their differentiation state, while white adipocytes inhibited macrophage

382 spreading supports the hypothesis that macrophage phenotype is dependent on the adipose tissue

383 microenvironment.

384 WAT has been well characterized. There are differences in $\mathrm{CD}^{+} 8^{+}$macrophages between

385 visceral and subcutaneous WAT [36]. “Obese” WAT has increased proinflammatory cytokine

386 transcripts [37,38] and secreted cytokines such as TNF [39], angiotensinogen, PAI-1,

387 PGAR/FIAF, IL-6, leptin, and resistin [40-42]. In particular, isolated adipocytes secrete TNF-

388 alpha, IL-6, IL-8, IL-1Ra, IL-10, leptin, adiponectin, resistin [41] and visfatin [40,43] and

389 various populations of $\mathrm{CD}_{14}{ }^{+} \mathrm{CD} 31^{+}$adipose tissue macrophages (ATMs) [40] or MGL1 ${ }^{+}$

390 ATMs have increased IL10, Arg1, and Pgclb transcript levels [44] or secrete MCP-1, MIP-1 $\alpha$ 
391 and IL-8 [43]. Nos2 and ILIb transcripts also go up in MGL1 ${ }^{-}$CCR2 $2^{+}$macrophage populations

392 around necrotic adipocytes [44]. One explanation for the differences may be the origins of the

393 tissues. Brown adipose cells may be more closely related to muscle cells than white adipose

394 cells [45,46]. Macrophages in normal muscle are angiogenic or anti-inflammatory [47]. In

395 addition, BAT and WAT express and secrete different autocrine, paracrine and endocrine

396 signals. WAT has been recognized as an endocrine organ. It produces and secretes a plethoric

397 collection of adipokines [48-50]. Among them for example, adipsin, leptin and adiponectin are

398 highly expressed in WAT, whereas their production in BAT is associated only with

399 thermogenically inactive BAT cells [51]. In contrast, BAT has been reported to express other

400 cellular mediators, such as basic fibroblast growth factor [52] and prostaglandins E2 and F2 $\alpha$

401 [53]. BAT cells also produce T4 thyroxine deiodinase type II [54] and nitric oxide synthase

402 enzymes (eNOS and iNOS) [55] which enables it to produce T3 and NO, respectively.

403 Uncoupling protein, unique to BAT, also exhibits chloride channel properties [56]. Chloride

404 channels can regulate NADPH oxidase membrane depolarization [57] and can regulate

405 phagocyte cell function [58]. Therefore, it is possible that BAT can regulate the C2D

406 macrophage cell phenotype because of UCP's unique ability to regulate oxidative metabolism.

407 While it is not clear at present what specific molecular mechanisms are responsible for the

408 distinct phenotypic differences between WAT-C2D and BAT-C2D, we have shown that there are

409 significant interactions between adipocytes and macrophages that is mediated by cytokines and

410 cell-cell contact that affects the differentiation and function of both macrophages and adipocytes

411 [35]. This current study extends the macrophage interaction to include brown adipocytes by

412 showing that $\mathrm{C} 2 \mathrm{D}$ macrophages traffic to the BAT and they acquire a phenotype unique to that 
413 tissue. The data support the hypothesis that macrophage plasticity is dependent upon

414 environmental signals and is not predetermined as some have suggested [10].

It is possible that the adoptive transfer technique or procedures used in recovering

417 macrophages for our study may have impacted the results. First, adoptive transfer could have

418 induced a peritonitis or inflammation in the adipose tissue. We do not believe this to be the case.

419 Although, we detected some neutrophils (28\% PMNs in PEC, 3\% in BAT and 10\% in WAT), the

420 lack of an acute inflammatory response where one would expect a large PMN inflammation

421 (>80\% PMN) [59] and extensive macrophage activation [60] suggests that we did not induce a

422 peritonitis or abnormal inflammation in these tissues. We found that the recipient host

423 macrophages that were isolated from the SVF had a similar cell surface phenotype to the WAT-

424 C2D cells. These data suggest that the C2D macrophages were acquiring a "resident

425 macrophage phenotype" as opposed to a proinflammatory phenotype which would be expected

426 of recently immigrating macrophages in obese mice $[18,43]$. This hypothesis is supported by

427 the fact that we saw inconsistent evidence of a proinflammatory phenotype in WAT-C2D

428 because both M1 (e.g. TNF- $\alpha$ ) and M2 (IL-10) [61,62] markers were up regulated. The

429 differential counts of the cells in WAT and BAT also did not reflect an inflammatory milieu.

430 The CD11b expression on WAT-C2D macrophages would also be reflective of cells which are

431 undergoing normal cell trafficking [63].

432 Ruan et al. found that the isolation of adipocytes with collagenase for 2 hours led to the

433 activation of the adipocytes when they were assayed in vitro [64]. Our macrophages were

434 isolated with a 40 minute collagenase treatment and that exposure could have affected them and

435 we cannot rule out this possibility. However, the adipocytes were separated from the 
macrophages quickly and the expression of some of the genes of interest (e.g. TNF and TNFR)

437 take several hours to upregulate [64]. In addition, if collagenase had a general activating action 438 on the C2D macrophage cells [65], we probably would not have seen the general down

439 regulation of $\mathrm{C} 2 \mathrm{D}$ macrophage cell gene transcripts in BAT unless BAT had a suppressive 440 environment.

441 Lastly, we were concerned that the $16 \mathrm{~h}$ incubation that we included before we assessed 442 surface marker expression could have affected the macrophage phenotype [66]. We see changes 443 in C2D macrophages when they are reintroduced to in vitro culture. However, two observations 444 suggest that the cell surface expressions we report are an accurate sampling of the C2D

445 macrophage phenotype. 1) The changes induced in vivo were still evident after an additional 16

446 hours of in vitro culture and 2) the differential expression of surface markers such as CD11b in

447 BAT and WAT paralleled the general changes in transcript level in those same tissues. The

448 RNA used for those analyses was not subject to the $16 \mathrm{~h}$. incubations.

449 In summary, the WAT microenvironment altered C2D macrophage cells differently than

450 BAT. The changes in WAT were dependent upon the differentiation of both the macrophages

451 and the adipocytes. In addition, WAT caused C2D macrophage cells to upregulate many genes

452 and molecules compared to when they were isolated from BAT. To our knowledge, this is the

453 first study to directly compare the macrophages that have recently trafficked to different adipose

454 tissues in the absence of complicating chronic diseases or altered genetic states. The evidence

455 that infiltrating macrophages begin to display unique tissue-specific phenotypes in normal mice

456 reaffirms the adaptive nature of macrophages to their environment. Determining the properties

457 of adipose tissue that make BAT and WAT so different may give us clues on how to regulate

458 macrophages to prevent disease.

459 


\section{Acknowledgements}

461 We thank Ms. Tammy Koopman for her assistance with flow cytometry, Dr. Dan Boyle 462 for his help with confocal microscopy, and Dr. Kurt Zhang for his help with statistical analysis. 463 We thank Ms. Alison Luce-Fedrow for her laboratory assistance and Ms. Lea Dib for her input 464 and review of the manuscript. This project has been supported by American Heart Association 465 grant 0950036G, NIH grants AI55052, AI052206, AI088070, RR16475, RR17686, RR17708, 466 NASA grants NAG2-1274 and NNX08BA91G, European Commission (Grant HEALTH-F4467 2008-223450), funding from Diabetes UK and the Wellcome Trust, the Kansas Agriculture 468 Experiment station and the Terry C. Johnson Center for Basic Cancer Research. This is Kansas 469 Agriculture Experiment Station publication 09-132-J. 


\section{References}

472

473

474

475

476

477

478

479

480

481

482

483

484

485

486

487

488

489

490

491

492

493

494

495

496

497

498

499

500

501

502

503

504

505

506

507

508

509

510

511

512

513

514

515

[1] M. Meltzer, M. Occhionero, and L. Ruco, Macrophage activation for tumor cytotoxicity: Regulatory mechanisms for induction and control of cytotoxic activity. Fed. Proc. 41 (1982) 2198-2205.

[2] L. Ruco, and M. Meltzer, Macrophage activation for tumor cytotoxicity: Induction of tumoricidal macrophages by supernatants of PPD-stimulated Bacillus Calmette-Guerinimmune spleen cell cultures. J. Immunol. 119 (1977) 889-896.

[3] W. Wiktor-Jedrzejczak, B. Dzwigala, M. Szperl, M. Maruszynski, E. Urbanowska, and P. Szwech, Colony-stimulation factor 1-dependent resident macrophages play a regulatory role in fighting Escherichia coli fecal peritonitis. Infect. Immun. 64 (1996) 1577-1581.

[4] T.K. Held, X. Weihua, L. Yuan, D.V. Kalvakolanu, and A.S. Cross, Gamma interferon augments macrophage activation by lipopolysaccharide by two distinct mechanisms, at the signal transduction level and via an autocrine mechanism involving tumor necrosis factor alpha and interleukin-1. Infect Immun 67 (1999) 206-12.

[5] M. Dorger, S. Munzing, A.M. Allmeling, K. Messmer, and F. Krombach, Phenotypic and functional differences between rat alveolar, pleural, and peritoneal macrophages. Exp Lung Res 27 (2001) 65-76.

[6] J.F. Cailhier, M. Partolina, S. Vuthoori, S. Wu, K. Ko, S. Watson, J. Savill, J. Hughes, and R.A. Lang, Conditional macrophage ablation demonstrates that resident macrophages initiate acute peritoneal inflammation. J Immunol 174 (2005) 2336-42.

[7] K. Takahashi, M. Naito, and M. Takeya, Development and heterogeneity of macrophages and their related cells through their differentiation pathways. Pathol Int 46 (1996) 473-85.

[8] M. Naito, S. Umeda, T. Yamamoto, H. Moriyama, H. Umezu, G. Hasegawa, H. Usuda, L. Shultz, and K. Takahashi, Development, differentiation, and phenotypic heterogeneity of murine tissue macrophages. J Leukoc Biol 59 (1996) 133-138.

[9] S. Gordon, and P.R. Taylor, Monocyte and macrophage heterogeneity. Nat Rev Immunol 5 (2005) 953-64.

[10] F. Geissmann, M.G. Manz, S. Jung, M.H. Sieweke, M. Merad, and K. Ley, Development of monocytes, macrophages, and dendritic cells. Science 327 (2010) 656-61.

[11] M.S. Rutherford, A. Witsell, and L.B. Schook, Mechanisms generating functionally heterogeneous macrophages: chaos revisited. J Leukoc Biol 53 (1993) 602-18.

[12] D.L. Laskin, B. Weinberger, and J.D. Laskin, Functional heterogeneity in liver and lung macrophages. J Leukoc Biol 70 (2001) 163-70.

[13] R.D. Stout, and J. Suttles, Functional plasticity of macrophages: reversible adaptation to changing microenvironments. J Leukoc Biol 76 (2004) 509-13.

[14] F. Geissmann, S. Jung, and D.R. Littman, Blood monocytes consist of two principal subsets with distinct migratory properties. Immunity 19 (2003) 71-82.

[15] B.E. Potts, M.L. Hart, L.L. Snyder, D. Boyle, D.A. Mosier, and S.K. Chapes, Differentiation of C2D macrophage cells after adoptive transfer. Clin Vaccine Immunol 15 (2008) 243-252.

[16] B.E. Potts, and S.K. Chapes, Functions of C2D macrophage cells after adoptive transfer. J Leukoc Biol 83 (2008) 602-609.

[17] J.N. Fain, A.K. Madan, M.L. Hiler, P. Cheema, and S.W. Bahouth, Comparison of the release of adipokines by adipose tissue, adipose tissue matrix, and adipocytes from 
visceral and subcutaneous abdominal adipose tissues of obese humans. Endocrinology 145 (2004) 2273-82.

[18] G. Fantuzzi, Adipose tissue, adipokines, and inflammation. J Allergy Clin Immunol 115 (2005) 911-9; quiz 920.

[19] S. Klaus, Functional differentiation of white and brown adipocytes. Bioessays 19 (1997) 215-23.

[20] K. Adachi, M. Miki, H. Tamai, M. Tokuda, and M. Mino, Adipose tissues and vitamin E. J Nutr Sci Vitaminol (Tokyo) 36 (1990) 327-37.

[21] J. Himms-Hagen, Brown adipose tissue thermogenesis: interdisciplinary studies. Faseb J 4 (1990) 2890-8.

[22] J. Nedergaard, T. Bengtsson, and B. Cannon, Unexpected evidence for active brown adipose tissue in adult humans. Am J Physiol Endocrinol Metab 293 (2007) E444-52.

[23] K.A. Virtanen, M.E. Lidell, J. Orava, M. Heglind, R. Westergren, T. Niemi, M. Taittonen, J. Laine, N.J. Savisto, S. Enerback, and P. Nuutila, Functional brown adipose tissue in healthy adults. N Engl J Med 360 (2009) 1518-25.

[24] P. Lee, J.R. Greenfield, K.K. Ho, and M.J. Fulham, A critical appraisal of prevalence and metabolic significance of brown adipose tissue in adult humans. Am J Physiol Endocrinol Metab (2010).

[25] J.A. Villena, B. Cousin, L. Penicaud, and L. Casteilla, Adipose tissues display differential phagocytic and microbicidal activities depending on their localization. Int J Obes Relat Metab Disord 25 (2001) 1275-80.

[26] A.A. Beharka, J.W. Armstrong, and S.K. Chapes, Macrophage cell lines derived from major histocompatibility complex II-negative mice. In Vitro Cell. Dev. Biol. 34 (1998) 499507.

[27] L. Xie, D. Boyle, D. Sanford, P.E. Scherer, J.E. Pessin, and S. Mora, Intracellular trafficking and secretion of adiponectin is dependent on GGA-coated vesicles. J Biol Chem 281 (2006) 7253-9.

[28] M. Rodbell, Localization of Lipoprotein Lipase in Fat Cells of Rat Adipose Tissue. J Biol Chem 239 (1964) 753-5.

[29] M. Rodbell, Metabolism of Isolated Fat Cells. I. Effects of Hormones on Glucose Metabolism and Lipolysis. J Biol Chem 239 (1964) 375-80.

[30] P. Seale, S. Kajimura, W. Yang, S. Chin, L.M. Rohas, M. Uldry, G. Tavernier, D. Langin, and B.M. Spiegelman, Transcriptional control of brown fat determination by PRDM16. Cell Metab 6 (2007) 38-54.

[31] M. Murholm, K. Dixen, K. Qvortrup, L.H. Hansen, E.Z. Amri, L. Madsen, G. Barbatelli, B. Quistorff, and J.B. Hansen, Dynamic regulation of genes involved in mitochondrial DNA replication and transcription during mouse brown fat cell differentiation and recruitment. PLoS One 4 (2009) e8458.

[32] M.W. Pfaffl, A new mathematical model for relative quantification in real-time RT-PCR. Nucleic Acids Res 29 (2001) e45.

[33] B.M. Phillips, J.W. Hunt, B.S. Anderson, H.M. Puckett, R. Fairey, C.J. Wilson, and R. Tjeerdema, Statistical significance of sediment toxicity test results: threshold values derived by the detectable significance approach. Environ Toxicol Chem 20 (2001) 371-3. [34] J.G. Neels, and J.M. Olefsky, Inflamed fat: what starts the fire? J Clin Invest 116 (2006) 335. 
[35] L. Xie, M.T. Ortega, S. Mora, and S.K. Chapes, Interactive changes between macrophages and adipocytes. Clin Vaccine Immunol 17 (2010) 651-9.

[36] A. Bouloumie, C.A. Curat, C. Sengenes, K. Lolmede, A. Miranville, and R. Busse, Role of macrophage tissue infiltration in metabolic diseases. Curr Opin Clin Nutr Metab Care 8 (2005) 347-54.

[37] G. Hotamisligil, N. Shargill, and B. Spiegelman, Adipose expression of tumor necrosis factor-alpha: Direct role in obesity-linked insulin resistance. Science 259 (1993) 87-91.

[38] V. Rotter, I. Nagaev, and U. Smith, Interleukin-6 (IL-6) induces insulin resistance in 3T3L1 adipocytes and is, like IL-8 and tumor necrosis factor-alpha, overexpressed in human fat cells from insulin-resistant subjects. J Biol Chem 278 (2003) 45777-84.

[39] R. Cancello, J. Tordjman, C. Poitou, G. Guilhem, J.L. Bouillot, D. Hugol, C. Coussieu, A. Basdevant, A. Bar Hen, P. Bedossa, M. Guerre-Millo, and K. Clement, Increased infiltration of macrophages in omental adipose tissue is associated with marked hepatic lesions in morbid human obesity. Diabetes 55 (2006) 1554-61.

[40] G. Fantuzzi, Adipose tissue, adipokines, and inflammation. J Allergy Clin Immunol 115 (2005) 911-9.

[41] M. Guerre-Millo, Adipose tissue hormones. J Endocrinol Invest 25 (2002) 855-61.

[42] H. Ruan, and H.F. Lodish, Insulin resistance in adipose tissue: direct and indirect effects of tumor necrosis factor-alpha. Cytokine Growth Factor Rev 14 (2003) 447-55.

[43] C.N. Lumeng, J.B. DelProposto, D.J. Westcott, and A.R. Saltiel, Phenotypic switching of adipose tissue macrophages with obesity is generated by spatiotemporal differences in macrophage subtypes. Diabetes 57 (2008) 3239-46.

[44] T.J. Guzik, D. Mangalat, and R. Korbut, Adipocytokines - novel link between inflammation and vascular function? J Physiol Pharmacol 57 (2006) 505-28.

[45] Y.H. Tseng, E. Kokkotou, T.J. Schulz, T.L. Huang, J.N. Winnay, C.M. Taniguchi, T.T. Tran, R. Suzuki, D.O. Espinoza, Y. Yamamoto, M.J. Ahrens, A.T. Dudley, A.W. Norris, R.N. Kulkarni, and C.R. Kahn, New role of bone morphogenetic protein 7 in brown adipogenesis and energy expenditure. Nature 454 (2008) 1000-4.

[46] P. Seale, B. Bjork, W. Yang, S. Kajimura, S. Chin, S. Kuang, A. Scime, S. Devarakonda, H.M. Conroe, H. Erdjument-Bromage, P. Tempst, M.A. Rudnicki, D.R. Beier, and B.M. Spiegelman, PRDM16 controls a brown fat/skeletal muscle switch. Nature 454 (2008) 961-7.

[47] L. Arnold, A. Henry, F. Poron, Y. Baba-Amer, N. van Rooijen, A. Plonquet, R.K. Gherardi, and B. Chazaud, Inflammatory monocytes recruited after skeletal muscle injury switch into antiinflammatory macrophages to support myogenesis. J. Exp. Med. 204 (2007) 1057-1069.

[48] R.S. Ahima, and J.S. Flier, Adipose tissue as an endocrine organ. Trends Endocrinol Metab 11 (2000) 327-32.

[49] E. Maury, and S.M. Brichard, Adipokine dysregulation, adipose tissue inflammation and metabolic syndrome. Mol Cell Endocrinol (2009).

[50] S.E. Wozniak, L.L. Gee, M.S. Wachtel, and E.E. Frezza, Adipose tissue: the new endocrine organ? A review article. Dig Dis Sci 54 (2009) 1847-56.

[51] B. Cannon, and J. Nedergaard, Brown adipose tissue: function and physiological significance. Physiol Rev 84 (2004) 277-359.

[52] A. Asano, K. Kimura, and M. Saito, Cold-induced mRNA expression of angiogenic factors in rat brown adipose tissue. J Vet Med Sci 61 (1999) 403-9. 
[53] R. Portet, F. de Marco, L. Zizine, R. Bertin, and C. Senault, Perinatal variations of prostaglandins $\mathrm{E} 2$ and $\mathrm{F}$ alpha levels in brown adipose tissue of the rat; effects of ambient temperature. Biochimie 62 (1980) 715-8.

[54] J.E. Silva, and P.R. Larsen, Adrenergic activation of triiodothyronine production in brown adipose tissue. Nature 305 (1983) 712-3.

[55] K. Kikuchi-Utsumi, B. Gao, H. Ohinata, M. Hashimoto, N. Yamamoto, and A. Kuroshima, Enhanced gene expression of endothelial nitric oxide synthase in brown adipose tissue during cold exposure. Am J Physiol Regul Integr Comp Physiol 282 (2002) R623-6.

[56] S.G. Huang, and M. Klingenberg, Chloride channel properties of the uncoupling protein from brown adipose tissue mitochondria: a patch-clamp study. Biochemistry 35 (1996) 16806-14.

[57] J. Ahluwalia, Chloride channels activated by swell can regulate the NADPH oxidase generated membrane depolarisation in activated human neutrophils. Biochem Biophys Res Commun 365 (2008) 328-33.

[58] J.G. Moreland, A.P. Davis, G. Bailey, W.M. Nauseef, and F.S. Lamb, Anion channels, including ClC-3, are required for normal neutrophil oxidative function, phagocytosis, and transendothelial migration. J Biol Chem 281 (2006) 12277-88.

[59] S.K. Chapes, and S. Haskill, Evidence for granulocyte-mediated macrophage activation after C. parvum immunization. Cell. Immunol. 75 (1983) 367-377.

[60] E. Knudsen, P.O. Iversen, N. Van Rooijen, and H.B. Benestad, Macrophage-dependent regulation of neutrophil mobilization and chemotaxis during development of sterile peritonitis in the rat. Eur J Haematol 69 (2002) 284-96.

[61] M. Munder, K. Eichmann, and M. Modolell, Alternative metabolic states in murine macrophages reflected by the nitric oxide synthase/arginase balance: competitive regulation by CD4+ T cells correlates with Th1/Th2 phenotype. J Immunol 160 (1998) 5347-54.

[62] J.P. Edwards, X. Zhang, K.A. Frauwirth, and D.M. Mosser, Biochemical and functional characterization of three activated macrophage populations, 2006, pp. 1298-1307.

[63] H.E. Broxmeyer, S. Cooper, G. Hangoc, J.L. Gao, and P.M. Murphy, Dominant myelopoietic effector functions mediated by chemokine receptor CCR1. J Exp Med 189 (1999) 1987-92.

[64] H. Ruan, M.J. Zarnowski, S.W. Cushman, and H.F. Lodish, Standard Isolation of Primary Adipose Cells from Mouse Epididymal Fat Pads Induces Inflammatory Mediators and Down-regulates Adipocyte Genes. J. Biol. Chem. 278 (2003) 47585-47593.

[65] C. Moore, and J.C. Hutson, Physiological relevance of tumor necrosis factor in mediating macrophage-Leydig cell interactions. Endocrinology 134 (1994) 63-69.

[66] S.K. Watkins, N.K. Egilmez, J. Suttles, and R.D. Stout, IL-12 Rapidly Alters the Functional Profile of Tumor-Associated and Tumor-Infiltrating Macrophages In Vitro and In Vivo. J Immunol 178 (2007) 1357-1362. 
651 Fig. 1. Gating strategies for cell sorting of CFDA-SE positive macrophage cells and effects

653 macrophage cells were sorted based on negative expression of CFDA-SE, B) C2D CFDA-SE

654 macrophage cells were sorted based on positive CFDA-SE expression; C) Example of C2D

$655 \mathrm{CFDA}_{-\mathrm{SE}^{+} \text {cells that were sorted from a mixed cell sample such as C2D CFDA-SE }}^{+}$

656 macrophages (region 2) co-cultured with 3T3L1 adipocytes (region 1); D) PEC-C2D

657 macrophages were treated with isotype control antibody (top) or anti Mac-2 antibody (middle

658 and bottom) then assessed by flow cytometry. Cells were treated with PBS (middle) or

659 collagenase (bottom) for 40 minutes before antibody probing.

661 Fig. 2. Change in C2D macrophage cell morphology during co-cultured with adipocytes or 662 pre-adipocytes in vitro and after infiltration into BAT or WAT in vivo. A) C2D macrophage 663 cells were labeled with CFDA-SE or B) C2D macrophage cells labeled with CFDA-SE and 664 isolated from peritoneal cavity (PEC-C2D) were cultured a) alone or co-cultured with b) 3T3L1 665 pre-adipocytes or c) adipocytes as described in the Materials and Methods. Panels a, b and c; 666 Cells viewed on the fluorescent microscope (Magnification x 200). Panels d, e and f are phase 667 contrast images of cells in a, b and c. C) WAT-C2D and BAT-C2D were collected from mice 668 two days after adoptive transfer. C2 D macrophages, WAT and BAT were processed as 669 described in Materials and Methods. Panels a and c images from the confocal microscope (x 670 100). Panels $b$ and $d$ are phase contrast images of the same fields. 
672 Fig. 3. Phenotype changes of C2D macrophage cells co-cultured with adipocytes or pre-

673 adipocytes in vitro. C2D or PEC-C2D cells labeled with CFDA-SE were cultured alone or co-

674 cultured with 3T3L1 adipocytes or pre-adipocytes andthe cell mixtures were immunostained for

675 flow cytometry as described in Materials and Methods. C2D macrophage cells phenotypes were 676 analyzed within CFDA-SE ${ }^{+}$population. A) C2D macrophage cells grown in vitro were cultured

677 alone, co-cultured with 3T3L1 adipocytes or with pre-adipocytes. B) PEC-C2D macrophage

678 cells were cultured alone, co-cultured with adipocytes or with pre-adipocytes. The data is

679 presented as the mean \pm SEM ( $n=3$ independently collected samples per treatment group).

680 Different letters indicate a significant difference between control, preadipocytes or adipocytes for

681 CD11b (lower case) or Mac-2 (upper case) cell surface proteins. A $P$ value of $<0.05$ was 682 considered significant.

683

684 Figure 4. Phenotype changes in C2D macrophage cells isolated from WAT or BAT in vivo

685 after i.p. adoptive transfer. C2D macrophage cells were isolated from WAT and BAT and

686 immunostained to detect Ly-6C, Mac-2, CD11b and F4/80 by flow cytometry. A) Surface

687 marker expression was assessed on CFDA-SE-positive cells isolated from WAT or BAT. B)

688 Surface marker expression was assessed on CFDA-SE-positive cells (left) or CFDA-SE-negative

689 cells (right) in the stromal vascular fraction isolated from WAT. The data is represented as mean

$690 \pm \operatorname{SEM}(\mathrm{n}=3-6$ independently collected samples per adipose tissue type). Comparisons were

691 done between samples stained for the same surface markers in panels A or B. * indicates a

692 significant difference with a $P$ value of $<0.05$.

693 
694 Fig. 5. Expression analysis of C2D macrophage cells isolated from WAT or BAT. C2D

695 macrophage cells were isolated from BAT and WAT by collagenase treatment as described in

696 Materials and Methods. PEC-C2D (black bars), WAT-C2D (white bars) or BAT-C2D (grey bars)

697 were purified by FACS and gene transcripts were quantified by qRT-PCR as described in the

698 Materials and Methods. The data is presented as the mean \pm SEM ( $n=2$ independent RNA

699 samples; fat pads from 4 mice per pooled sample). Significant differences found between: *

700 PEC-C2D vs. WAT-C2D, PEC-C2D vs. BAT-C2D and WAT-C2D vs. BAT-C2D; † PEC-C2D

$701 v s$. BAT-C2D and WAT-C2D vs. BAT-C2D; § PEC-C2D vs. WAT-C2D and PEC-C2D vs.

702 BAT-C2D; - WAT-C2D vs. BAT-C2D; o PEC-C2D vs. WAT-C2D.

703

704

705

706

707 
1 Evaluation of macrophage plasticity in brown and white adipose tissue

4 M. Teresa Ortega ${ }^{1 \dagger}$, Linglin Xie ${ }^{1 \dagger}$, Silvia Mora $^{2}$, and Stephen K. Chapes ${ }^{1 *}$

$5 \quad{ }^{1}$ Division of Biology, Kansas State University, Manhattan, KS, 66506 and ${ }^{2}$ Department of

6 Cellular and Molecular Physiology, Institute of Translational Medicine, The University of

7 Liverpool, Crown Street, Liverpool L69 3BX, United Kingdom

$8 \uparrow$ Co-first authors

10 Running Title: Macrophage-adipose interactions

13 *Address correpondence to:

14 Stephen K. Chapes

15116 Ackert Hall

16 Kansas State University

17 Manhattan, KS 66506-4901

18 E mail:skcbiol@ksu.edu

19 Voice: 785-532-6795

20 Fax: 785-532-6653 


\section{ABSTRACT}

There are still questions about whether macrophage differentiation is predetermined or is

26 induced in response to tissue microenvironments. C2D macrophage cells reside early in the

27 macrophage lineage in vitro, but differentiate to a more mature phenotype after adoptive transfer

28 to the peritoneal cavity (PEC-C2D). Since C2D macrophage cells also traffic to adipose tissue

29 after adoptive transfer, we explored the impact of white adipose tissue (WAT), brown adipose

30 tissue (BAT) and in vitro cultured adipocytes on C2D macrophage cells.

31 When PEC-C2D macrophage cells were cultured with preadipocytes the cells stretched

32 out and CD11b and Mac-2 expression was lower compared to PEC-C2D macrophage cells

33 placed in vitro alone. In contrast, PEC-C2D cells co-cultured with adipocytes maintained

34 smaller, round morphology and more cells expressed Mac-2 compared to PEC-C2D co-cultured

35 with preadipocytes. After intraperitoneal injection, C2D macrophage cells migrated into both

36 WAT and BAT. A higher percentage of C2D macrophage cells isolated from WAT (WAT-

37 C2D) expressed Ly-6C (33\%), CD11b (11\%), Mac-2 (11\%) and F4/80 (29\%) compared to C2D

38 macrophage cells isolated from BAT (BAT-C2D). Overall, BAT-C2D macrophage cells had

39 reduced expression of many cytokine, chemokine and receptor gene transcripts when compared

40 to in vitro grown C2D macrophages, while WAT-C2D macrophage cells and PEC-C2D up-

41 regulated many of these gene transcripts. These data suggest that the $\mathrm{C} 2 \mathrm{D}$ macrophage

42 phenotype can change rapidly and distinct phenotypes are induced by different

43 microenvironments. 


\section{Introduction}

Macrophages are found throughout the body and serve as initiators and effectors of the

50 innate immune system [1-6]. Macrophages differentiate from bone marrow hematopoietic stem

51 cells through various stages including, macrophage-colony forming cells to monoblasts,

52 promonocytes and finally into monocytes [7,8]. Monocytes enter the bloodstream, where they

53 circulate before migrating into tissues. There they differentiate into tissue-specific macrophages

54 [9]. Macrophages are a heterogeneous group of cells which have different functions,

55 morphologies and phenotypic properties [7,9]. Heterogeneity is commonly associated with

56 macrophages as a consequence of the functions, organ sites and immune status of the host $[9,10]$.

57 However, there is controversy about macrophage adaptation to microenvironmental signals in

58 vivo [10-13]. Some think that since subpopulations of macrophages have either proinflammatory

59 (M1) or anti-inflammatory (M2) properties, there are predetermined fates for monocytes and

60 macrophages as opposed to the microenvironmental signaling leading to the macrophage

61 plasticity $[10,14]$.

62 C2D macrophage cells reside early in the macrophage lineage in vitro, but differentiate to

63 a more mature, phenotype after adoptive transfer to the peritoneal cavity (PEC-C2D) [15]. These

64 macrophage cells differentiate and traffic like primary macrophages and can provide insight into

65 macrophage function [16]. In particular, they can provide evidence about macrophage plasticity

66 in response to different microenvironments.

67 White adipose tissue (WAT) and brown adipose tissue (BAT) have distinct physiological

68 functions. WAT is an energy storage and endocrine organ [17,18]. In contrast, BAT functions

69 as an energy-dissipating organ through adaptive-thermogenesis [19]. These adipocyte depots

70 display different morphology, cellular characteristics, body localizations and function [19-24]. 
Previous studies have suggested that macrophage function varies considerably in

72 different fat depots [25]. Some have also suggested that macrophage plasticity is an artifact of in

73 vitro manipulations [10]. Given the controversy about macrophage adaptation to

74 microenvironmental signals in vivo [10-13] and the fact that little is known about BAT-

75 macrophage interactions, we investigated whether macrophage phenotype is predetermined or is 76 adaptable.

\section{Materials and methods}

\subsection{Mouse strains}

C57BL/6J (B6) mice were originally obtained from the Jackson Laboratory (Bar Harbor,

81 ME). Male and female, 8-16 week-old mice were bred in the rodent facility of the Division of

82 Biology at Kansas State University and used in these experiments. Mice were fed a normal

83 mouse chow diet (5001, PMI International, St. Louis, MO) and were allowed to feed Ad libitum.

84 All animal experiments were approved by the Institutional Animal Care and Use Committee.

\subsection{Antibodies and Reagents}

Collagenase (Type II), insulin from bovine pancreas, 3-Isobutyl-1-methylxanthine

88 (IBMX) and dexamethasone were obtained from Sigma-Aldrich Co. (St. Louis, MO).

89 Carboxyfluorescein diacetate, succinmidyl (CFDA-SE) ester was purchased from Molecular

90 probes (Eugene, OR). APC conjugated anti-CD11c, APC conjugated anti-F4/80, APC

91 conjugated anti-CD11b, ALEXA Fluor 647 conjugated anti-Mac2, and their isotype control

92 antibodies were purchased from eBioscience (San Diego, CA). Biotin conjugated anti-Ly-6C 
93 (ER-MP20) and its isotype control antibody were from BD Pharmingen (San Jose, CA). APC

94 conjugated Streptavidin was purchased from eBioscience (San Diego, CA).

\subsection{Cell lines and cell culture}

The C2D macrophage cell line was created as described by our group [26]. These cells

98 were derived from C2D mouse bone marrow and selected in the presence of macrophage colony

99 stimulating factor (M-CSF). These cells have the $\mathrm{MHCII}^{\prime-}$ and $\mathrm{Tlr} 4^{\mathrm{Lps}-\mathrm{n}}$ genotype and are

100 histocompatible with mice of the H-2 ${ }^{b}$ haplotype. C2D cells were grown in Dulbecco's

101 Modified Eagle's Medium with 4\% fetal bovine serum (DMEM $)$ supplemented with $0.3 \%$

102 Glutamax and 10\% Opti-MEM in 150-mm tissue culture plates.

103 3T3L1 adipocytes were obtained from the American Type Culture Collection (Manassas,

104 VA). Adipocytes were cultured and differentiated as described previously [27]. Briefly, 3T3L1

105 cell differentiation was induced by culturing cells in DMEM containing 10\% FBS (DMEM 10$), 1$

$106 \mu \mathrm{M}$ dexamethasone, $1.7 \mu \mathrm{M}$ insulin and $0.5 \mathrm{mM}$ IBMX for 4 days. On the fourth day, the

107 3T3L1 cells were cultured in $\mathrm{DMEM}_{10}$ with $1.7 \mu \mathrm{M}$ insulin. On day 8, 3T3L1 cells were

108 maintained in DMEM $_{10}$. Undifferentiated preadipocytes and adipocytes differentiated for 6-8

109 days were used in the experiments. 3T3L1 cells $\left(1 \times 10^{6}\right.$ cells $)$ were directly co-cultured with

$1101 \times 10^{6} \mathrm{C} 2 \mathrm{D}$ cells grown exclusively in vitro or $1 \times 10^{6}$ cells adoptively transferred C2D

111 macrophage cells isolated from the peritoneal cavity (PEC-C2D).

112 Bone marrow derived macrophages (BM-Mo) were differentiated from B6 mouse bone

113 marrow cells isolated from the femora, tibiae, and humeri. Briefly, the bones were recovered and

114 cleaned of all non-osseous tissue. The marrow cavity was flushed with a sterile PBS solution.

115 The red blood cells were lysed by incubating in ammonium chloride lysis buffer $\left(0.15 \mathrm{M} \mathrm{NH}_{4} \mathrm{Cl}\right.$, 
$11610 \mathrm{mM} \mathrm{KHCO}_{3}$, and $0.1 \mathrm{mM} \mathrm{Na} 2$ EDTA, $\mathrm{pH}$ 7.3) for $5 \mathrm{~min}$ in ice. Cells were centrifuged $(300 \mathrm{x}$

$117 \mathrm{~g}, 5 \mathrm{~min}$ ) and washed two times with $\mathrm{DMEM}_{2}$. Bone marrow cells were seeded and incubated in

118 M-CSF medium (DMEM 10 , OPTI-MEM, 0.01 M HEPES, 50 ng/ml gentamycin, $1.5 \mathrm{ng} / \mathrm{ml}$

119 rMCSF-1) for 7 days at $37{ }^{\circ} \mathrm{C}, 8 \% \mathrm{CO}_{2}$. BM-Mo were indirectly co-cultured with collagenase-

120 digested white adipose tissue (WAT) gonadal fat pads or collagenase- digested BAT perispleen

121 or interscapular fat pads as described below.

122

1232.4 Adoptive transfer of labeled cells

$124 \quad \mathrm{C} 2 \mathrm{D}$ cells were suspended in sterile, pre-warmed $\left(37^{\circ} \mathrm{C}\right)$ phosphate buffered saline (PBS;

$125137 \mathrm{mM} \mathrm{NaCl}, 10 \mathrm{mM}$ Phosphate, $2.7 \mathrm{mM} \mathrm{KCl}, \mathrm{pH} 7.4)$ at a concentration of $1.5 \times 10^{6}$ cells per $126 \mathrm{ml}$, further stained with CFDA-SE according to the manufacturer's protocol. Briefly, C2D cells 127 were incubated with $22 \mu \mathrm{M}$ of CFDA-SE solution at $37^{\circ} \mathrm{C}$ for 15 minutes. After centrifugation 128 at $370 \mathrm{x}$ g for 10 minutes, cell pellets were suspended in pre-warmed $\mathrm{PBS}$ and incubated in $37^{\circ} \mathrm{C}$ 129 for an additional 20 minutes. Cells were then washed twice in PBS, and suspended at a 130 concentration of $4 \times 10^{7}$ cells per $\mathrm{ml}$ in PBS. One and one-half $\mathrm{ml}$ of the cell suspension of 131 CFDA-SE labeled C2D or normal C2D cells was injected intraperitoneally (i.p.) per mouse.

\subsection{Peritoneal cell extraction and fat tissue isolation}

PEC-C2D macrophage cells were obtained from B6 mice by peritoneal lavage 36 hours

135 after intraperitoneal injection of $4 \times 10^{7}$ of C2D macrophage cells labeled with CFDA-SE. The 136 peritoneal exudate red blood cells were lysed as described in section 2.3. One-half of the cells 137 were treated with $1 \mathrm{mg} / \mathrm{ml}$ collagenase type II at $37^{\circ} \mathrm{C}$ with shaking $(60 \mathrm{rpm})$ for 40 minutes. 
138 Control or collagenase-treated cells were washed three times with PBS and $3 \times 10^{6}$ cells were 139 plated into 150-mm cell culture plates and incubated in $\mathrm{DMEM}_{4}$ for 16 hours. Isolation of adipocytes and CFDA-SE labeled C2D macrophage cells was performed as

141 previously described $[15,16]$. Adipocytes were isolated from both mouse gonadal fat pads

142 (depots connected to the uterus and ovaries in females and the epididymis and testes in males) 143 and perispleen adipose tissues by collagenase digestion [28,29]. We confirmed BAT origin by 144 quantitating the mRNA of PRDM16 by qRT-PCR [30] and/or UCP-1 [31] in tissues collected 145 from perispleen and interscapular isolates (data not shown). Gonadal fat pads weighed an 146 average of $268 \mathrm{mg}$ while perispleen fat averaged $98 \mathrm{mg}$. Interscapular fat pads weighed an 147 average of $61 \mathrm{mg}$. The fat pads were minced and incubated for $10 \mathrm{~min}$ in pre-warmed $\left(37^{\circ} \mathrm{C}\right)$ 148 Krebs-Ringer phosphate (KRP) buffer (12.5 mM HEPES, $120 \mathrm{mM} \mathrm{NaCl}, 6 \mathrm{mM} \mathrm{KCl}, 1.2 \mathrm{mM}$ $149 \mathrm{MgSO}_{4}, 1 \mathrm{mM} \mathrm{CaCl} 2,0.6 \mathrm{mM} \mathrm{Na}_{2} \mathrm{HPO}_{4}, 0.4 \mathrm{mM} \mathrm{Na}_{2} \mathrm{H}_{2} \mathrm{PO}_{4}, 2.5 \mathrm{mM} \mathrm{D}$-glucose, and $2 \%$ 150 bovine serum albumin, $\mathrm{pH}$ 7.4), thereafter the samples were incubated with Type II collagenase $151(1 \mathrm{mg} / \mathrm{ml})$ for $40 \mathrm{~min}$ at $37^{\circ} \mathrm{C}$ with constant shaking at $60 \mathrm{rpm}$. The WAT or BAT cells were 152 passed through a $100 \mu \mathrm{m}$ cell strainer; cells were then centrifuged at $370 \mathrm{x}$ g for 1 minute and 153 washed with Krebs Ringer buffer twice. Additionally, the adipocytes isolated from the paired 154 gonadal fat pads were separated into 2 major fractions. The floating upper layer was primarily 155 white adipocytes and the pelleted fraction was a mixture of stromal-vascular fraction (SVF) cells 156 containing macrophages. Both cell fractions were collected and washed twice with KRP buffer. 157 WAT and BAT cells were scored for numbers and viability on a hemacytometer using 158 trypan blue exclusion. Viability was $91 \pm 0 \%, 81 \pm 3 \%$ and $87 \pm 0 \%$ for PEC, BAT and SVF cells, 159 respectively, after isolation and collagenase treatment. In collagenase-digested samples, we 160 isolated an average of $1.3 \times 10^{5} \mathrm{C} 2 \mathrm{D}$ macrophage cells per mouse from gonadal WAT and $8.9 \times$ 
$16110^{4} \mathrm{C} 2 \mathrm{D}$ macrophage cells from perispleen BAT or $3.5 \times 10^{4} \mathrm{C} 2 \mathrm{D}$ macrophage cells from

162 interscapular BAT. $1 \times 10^{5}$ cells were pelleted onto a cytospin slide for differential staining. A

163 mixture of white adipocytes (upper layer) and $\mathrm{SVF}$ cells was co-incubated at $37^{\circ} \mathrm{C}$ in $\mathrm{DMEM}_{10}$,

164 for 16 hours at a concentration of $1 \times 10^{5}$ cells $/ \mathrm{ml}$ in a $150-\mathrm{mm}$ culture dish. The adipocytes

165 remained dispersed in the medium and the SVF cells attached to the $150-\mathrm{mm}$ culture plate. The

166 adipocytes isolated from perispleen adipose were collected from the cell pellets and washed

167 twice with KRP buffer. Cells isolated from perispleen BAT $\left(3 \times 10^{6}\right)$ were cultured at $37^{\circ} \mathrm{C}$ in

168 DMEM $_{10}$ in a $150-\mathrm{mm}$ culture plate for 16 hours.

169

1702.6 Flow cytometry analysis of C2D macrophage cells

171 Cell sorting was based on C2D macrophage cell CFDA-SE fluorescence, with the lowest

$17210 \%$ of the positive cells not selected. Briefly, cell sorting was performed with either a

173 FACSVantage SE cell sorter (Becton Dickson. Rockville, MD) or a MoFlo XDP Sterile Cell

174 Sorter (Beckman Coulter), using specimen optimization and calibration techniques according to

175 the manufacture's recommendations. Cells were sorted at a rate of 15,000 cells per second and

176 approximately $1 \times 10^{6}$ viable (trypan blue exclusion), positive cells per group were collected on

177 ice and centrifuged at $350 \mathrm{xg}$ for $5 \mathrm{~min}$ at $4^{\circ} \mathrm{C}$ for PCR Array or qRT-PCR analysis.

178 We found a loss of cell surface markers following collagenase treatment. For example,

179 Mac-2 was down regulated over 50\% after a 40 minute collagenase treatment based on control

180 PEC-C2D (data not shown). However, we were also concerned that this incubation would also

181 influence the cells. Therefore, we also evaluated the changes in TNF gene expression over time

182 after the PEC-C2D cells were cultured in vitro. We found C2D macrophage gene expression

183 was reduced some but was still positive for at least 24 hrs (data not shown). Therefore, we felt a 
184 reasonable approach to phenotype the cell surface molecules of the recovered C2D macrophage

185 cells from PEC, BAT and WAT would be to allow the cells to recover in vitro for 16 hours at

$18637^{\circ} \mathrm{C}$ in medium. Therefore, control or collagenase-treated C2D macrophage cells isolated from

187 the peritoneal cavity (PEC-C2D), WAT and BAT were resuspended in $\mathrm{DMEM}_{4}$ and incubated

188 for 16 hours prior to labeling cell surface proteins and assessment by flow cytometry.

189 Cells were transferred to wells of 96-well, round-bottom plates and they were blocked 190 with PBS-goat serum $(50: 50 ; 50 \mu \mathrm{l})$ at $4{ }^{\circ} \mathrm{C}$ for 0.5 hour. Subsequently, macrophage cell surface

191 proteins were identified by direct labeling. Briefly, blocked cells were incubated with the isotype 192 or specific antibody diluted in Hank's Buffered Salt Solution (HBSS; 0.137 M NaCl, 5.4 mM

$193 \mathrm{KCl}, 0.25 \mathrm{mM} \mathrm{Na}_{2} \mathrm{HPO}_{4}, 0.44 \mathrm{mM} \mathrm{KH}_{2} \mathrm{PO}_{4}, 1.3 \mathrm{mM} \mathrm{CaCl}_{2}, 1.0 \mathrm{mM} \mathrm{MgSO}$, $4.2 \mathrm{mM} \mathrm{NaHCO}_{3}$ )

194 for 1 hour in the dark at $4^{\circ} \mathrm{C}$. After two washes with HBSS, cells were fixed in $1 \%$ formalin.

195 Labeled cell surface proteins were assessed by flow cytometry. We gated on live, CFDA-SE-

196 positive or CFDA-SE negative cells, subsequently we assayed for the presence or absence of the 197 selected cell surface markers.

1992.7 Real time quantitative RT-PCR analysis

200 RNA was obtained by suspending the pelleted cells in $1 \mathrm{ml}$ of TriReagent (Molecular

201 Research Center). The solution was transferred to $2.0 \mathrm{ml}$ Heavy Phase Lock Gel tubes (5

202 Prime). $200 \mu \mathrm{l}$ of chloroform was added and the mixture was shaken for 15 seconds. The

203 samples were then centrifuged at $12,000 \mathrm{x}$ g for 10 minutes at $4{ }^{\circ} \mathrm{C}$ and the aqueous phase was

204 transferred to clean $1.5 \mathrm{ml}$ tubes. $500 \mu \mathrm{l}$ of isopropanol was added and RNA was precipitated at $205-20^{\circ} \mathrm{C}$ for 24 hours. Samples were subsequently centrifuged at $12,000 \mathrm{x} g$ for 10 minutes. The 206 RNA pellet was washed with $1 \mathrm{ml}$ of $70 \%$ ethanol and samples were centrifuged at $7.4 \mathrm{x} \mathrm{g}$ for 5 
207 minutes. The 70\% ethanol was decanted from the pellet; the pellet was allowed to slightly air 208 dry and was resuspended in $50 \mu 1$ of nuclease-free water. RNA samples were purified and 209 DNAse treated with EZRNA total RNA kit (Omega Bio-Tek, Inc.). One step qRT-PCR was 210 performed using the SuperScript III Platinum SYBR Green kit (Invitrogen; Carlsbad, CA)

211 according to the manufacturer's protocol. Primers were designed with the PrimerQuest software

212 (IDT; http://www.idtdna.com) using sequence data from NCBI sequence database as following:

213 TNF- $\left.\alpha \mathrm{NM} \_013693\right)$ forward 5'-tctcatgcaccaccatcaaggact and reverse 5'-

214 tgaccactctccctttgcagaact; IL-6 NM_031168.1) forward 5'-tctcatgcaccaccatcaaggact and reverse

215 5'- tgaccactctccetttgcagaact; ILI- $\beta$ NM_008361) forward 5'-aagggctgcttccaaacctttgac and reverse

216 5'-atactgectgcetgaagctcttgt; Arg-1(NM_007482) forward 5'-tggctttaacettggcttgcttcg and reverse

217 5'-catgtggcgcattcacagtcactt; Ym-1 (M94584) forward 5'-caccatggccaagctcattcttgt and reverse 5'-

218 tattggcctgtccttagcccaact; Fizz-1(NM_020509.3) forward 5'-actgcetgtgcttactcgttgact and reverse

219 5'-aaagctgggttctccacctcttca; Prdm16 (BC059838) forward 5'-tcatcccaggagagctgcatcaaa and

220 reverse 5'-atcacaggaacacgctacacggat; Ucp-1 (NM009463.3) forward 5'-ttgagctgctccacagcgcc

221 and reverse 5' -gttgcctgatgcgggcacga; $\beta$-actin (NM_007393) forward 5'-

222 tgtgatggtgggaatgggtcagaa and reverse 5 '-tgtggtgccagatcttctccatgt. The qRT-PCRs were

223 performed in a Cepheid SmartCycler System (Sunnyvale, CA). Fold increase in transcript

224 expression was calculated: E (gene of interest) ${ }^{\Delta c t \text { target }} / \mathrm{E}$ ( housekeeping) ${ }^{\Delta c t \text { housekeeping }}$ where $\mathrm{E}$

225 (efficiency) $=10^{(-1 / \text { slope })}$ as was previously described [32].

2262.8 PCR array analysis

227 Expression analysis of 84 cytokines, chemokines and corresponding receptor genes

228 involved in inflammatory responses was performed with the mouse inflammatory cytokines and 229 receptors $\mathrm{RT}^{2}$ profiler $^{\mathrm{TM}}$ PCR array system (SuperArray Bioscience Corporation, Frederick, 
230 MD). $1.2 \mu \mathrm{g}$ of total RNA was obtained from CFDA SE labeled C2D cells sorted from the PEC,

231 WAT, and BAT of C57BL/6J mice ( $\mathrm{n}=2$ pooled RNA samples, 4 mice per pooled sample).

232 Genomic DNA was digested with RNAse-free DNAase, followed by first strand cDNA synthesis

233 and then quantitative mRNA analysis according to manufacturer's protocol. The quantitative

234 real-time PCR array was done on a BioRad iCycler (BioRad Laboratory, Hercules, CA)

235 performed with the $\mathrm{RT}^{2}$ SYBR Green/Fluorescein qPCR Master Mix (SuperArray Bioscience

236 Corporation, Frederick, MD). Expression of mRNA for each gene was normalized to the

237 expression of $\beta$-actin and compared to the data obtained with the negative control (RNA from

238 cultured C2D cells) according to the $\Delta \Delta \mathrm{Ct}$ method [32].

\subsection{Immunofluorescence and image analysis}

Gonadal fat pads and perispleen adipose tissue were washed in Krebs-Ringer phosphate

242 (KRP) buffer fixed in 10\% formalin/PBS and were cut into 50- $\mu \mathrm{m}$-thick slices using a TC-2

243 tissue sectioner (Sorvall Instruments). Tissue slices were mounted onto glass slides, and

244 differential contrast interference (DIC) images of tissue and CFDA SE-labeled C2D macrophage

245 cells were observed on a model LSM 5 Pascal Zeiss laser scanning confocal microscope. Tissues

246 were visualized with 20X/0.5 and 40X/0.75 Plan Neofluor objectives with DIC. CFDA SE-

247 labeled C2D macrophage cells were visualized using the 488-nm line of an argon ion gas laser

248 (excitation of CFDA SE), an FT 488 primary dichroic beam splitter, a FT 545 secondary dichroic

249 beam slitter, a 505-nm to 530-nm-bandpass filter, a photomultiplier tube, and LSM5 Pa software,

250 version 3.2 SP2. The number of CFDA SE-labeled macrophages per square micrometer of area

251 of adipose tissue was determined using ImageJ v1.37 (NIH). Images were then imported to

252 Adobe Photoshop (Adobe Systems, Inc.) for figure processing. 
$254 \quad 2.10$ Statistical analysis.

255 Flow cytometry data, cell distribution data and qRT-PCR data were presented as the 256 mean \pm standard error of mean $(\mathrm{SEM})$ of independent experiments $(\mathrm{n}=3$ samples, 3 mice per 257 sample unless stated otherwise in the Figure legend). Differences in mean were determined 258 using Student's $t$ test (paired, two-tailed) or were determined using the Mann-Whitney rank-sum

259 test. Differences in cell distribution were assessed using the Chi-Square $\left(\chi^{2}\right)$ test. All tests were 260 calculated using the StatMost statistical package (Data XIOM, Los Angeles, CA). Differences 261 were considered significantly different when $P<0.05$. To assess differences in the samples 262 assayed in the PCR Arrays the mean Ct values between macrophage isolates were compared 263 using minimum significant difference (MSD) [33]. Any difference between means greater than 264 or equal to the MSD was considered to be a statistically different, while differences less than the 265 minimum significant difference were considered to be non-significant. An MSD was calculated 266 using the following equation: $\mathrm{MSD}=2 \times\left(\mathrm{s} \_\right.$pool $) \times(\sqrt{ }(1 / \mathrm{n} 1+1 / \mathrm{n} 2))$, where s pool is the standard 267 deviation pooled across all genes and all groups, $\mathrm{n} 1$ and $\mathrm{n} 2$ are the numbers of replicates for the 268 two treatments. In this study, $\mathrm{n} 1=\mathrm{n} 2=2$, and the pooled standard deviation was equal to 1.61 and 269 the MSD was equal to 3.22.

271 3. Results

2723.1 Morphological and phenotypic changes of C2D macrophage cells in response to adipocytes 273 in vitro

274 To determine how different tissue environments impact macrophage phenotypes, we 275 investigated macrophage responses to preadipocytes and adipocytes. In our experiments we used 
276 the C2D macrophage cell line and 3T3L1 cells before or after, differentiation into adipocytes.

277 We previously established the specific macrophage phenotype expressed by C2D cells after they 278 were injected i.p. (PEC-C2D) or before they respond to other microenvironments $[15,16,26]$. In 279 order to visualize and identify the C2D macrophages, C2D cells were labeled with CFDA-SE 280 prior to their injection into the animals or their co-culture with (3T3L1) preadipocyte/adipocyte 281 cells in vitro for two days. Subsequently, these cells were recovered and analyzed by

282 fluorescence-activated cell sorting. Cells from peritoneal lavages, BAT and SVF cells from 283 WAT were sorted by FACS analysis as described in Figure 1. C2D cells grown in vitro (Figure 284 1A, region 1) and C2D CFDA-SE cells (Figure 1B, region 2) were used as negative and positive 285 controls for gating, respectively, and for sorting C2D CFDA-SE positive cells from mixed cell 286 samples such as C2D CFDA-SE macrophages co-cultured with 3T3L1 adipocytes (Figure 1C). In comparison to the larger stretched morphology of C2D macrophage cells grown in 288 vitro (Figure 2A, panels a and d), the PEC-C2D macrophage cells were round after cell isolation 289 (Figure 2B, panels a and d). When C2D or PEC-C2D macrophage cells were cultured with 290 preadipocytes, the cells stretched out (Figure 2A and 2B, panels b and e). In contrast, when C2D 291 macrophage cells or PEC-C2D cells were co-cultured with differentiated 3T3L1 adipocytes, we 292 found that the cells maintained a mostly smaller, round morphology (Figure 2A and 2B, panels c 293 and f), suggesting that differentiated 3T3L1 adipocytes inhibit normal adherence and stretching 294 of the C2D macrophage cells.

295 The morphological differences in C2D and PEC-C2D macrophage cells co-cultured with 296 adipocytes were accompanied by changes in cell phenotype defined by cell surface molecules 297 detected using flow cytometry. In vitro, $15 \%$ of the C2D macrophage cells expressed Mac-2 but 298 not CD11b; indicative of an immature macrophage phenotype [15]. C2D macrophage cells 
acquire a more differentiated phenotype after adoptive transfer in vivo with high levels of

300 macrophage-specific molecules CD11b, Mac2, F4/80, cfms and low levels of CD11c, and Gr-1

301 (Ly6G) $[15,16]$. We observed no change in the numbers of cells that expressed either of the cell

302 surface markers on C2D macrophage cells co-cultured with pre-adipocytes compared to C2D

303 macrophage cells cultured alone (Figure 3A). However, we observed a statistically significant

$304 \quad(P<0.05)$ increase in the number of C2D macrophages that expressed CD11b when co-cultured

305 with 3T3L1 adipocytes (Figure 3A). For PEC-C2D macrophage cells, their maturation in the

306 peritoneal cavity is accompanied by an increase in the number of cells that express CD11b

307 [15,16]. Significantly more PEC-C2D macrophage cells co-cultured in vitro with adipocytes

308 expressed Mac-2 than PEC-C2D macrophage cells cultured alone or with preadipocytes (Figure

$3093 \mathrm{~B}, P<0.05)$. We observed a significant decrease $(P<0.05)$ in the number of PEC-C2D

310 macrophage cells expressing CD11b and Mac-2 when incubated with preadipocytes (Figure 3B).

3123.2 Assessment of C2D macrophage cells after trafficking into WAT and BAT

313 We previously found that C2D macrophage cells could be isolated from gonadal WAT

314 [15]. However, macrophage trafficking to BAT has not been well characterized. We used

315 confocal microscopy to visualize and count C2D macrophages in WAT and BAT. We counted

316 an average of $97 \mathrm{C} 2 \mathrm{D}$ macrophages $/ \mathrm{mm}^{2}$ in BAT compared to $146 \mathrm{C} 2 \mathrm{D}$ macrophages $/ \mathrm{mm}^{2}$ in

317 WAT ( $P>0.05$, $\mathrm{T}$ test, $\mathrm{n} \geq 9$ fields scored per tissue; Figure $2 \mathrm{C})$. We also assessed if $\mathrm{C} 2 \mathrm{D}$

318 macrophage immigration to WAT and BAT induced inflammation. We did differential staining

319 of white blood cells isolated from the adipose tissue $36 \mathrm{hrs}$ after i.p. injection of C2D

320 macrophage cells. This survey revealed distinct cell distributions. The white cell distribution in

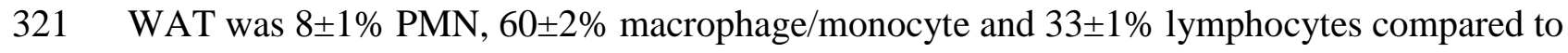


$3223 \pm 2 \%$ PMN, $79 \pm 2 \%$ macrophage/monocytes and $18 \pm 1 \%$ lymphocytes in BAT $\left(P<0.01 ; \chi^{2}\right.$ test $)$.

323 We also assessed C2D macrophage cell localization within WAT and BAT. WAT-C2D

324 appeared between adipocytes and some appeared to spread around the adipose cells (Figure 2C,

325 panels a, c, e). In contrast, BAT-C2D appeared only between adipocytes and generally had a

326 round appearance (Figure 2C, panels b, d, f).

327 To determine if the C2D macrophage cells isolated from BAT and WAT maintained the 328 same phenotype they expressed in the peritoneum or if they responded to the different tissue 329 environments, we compared BAT-C2D and WAT-C2D for the expression of Ly-6C, Mac-2,

$330 \mathrm{CD} 11 \mathrm{~b}$ and F4/80. Cells were labeled with CFDA and the CFDA-SE positive cells were

331 assessed (Figure 4A). We observed that 33\% of the WAT-C2D expressed Ly-6C, while there

332 were very few Ly6C-positive (<1\%) BAT-C2D. A significantly higher number of WAT-C2D

333 macrophage cells expressed $(P<0.05)$ Mac-2 compared to BAT-C2D macrophage cells. We

334 observed over 30\% of the WAT-C2D macrophage cells expressed F4/80, but almost no BAT-

335 C2D expressed F4/80 (Figure 4A). Significantly more WAT-C2D cells expressed CD11b than

336 BAT-C2D (Figure 4A). When we compared C2D macrophage phenotype to the phenotype of

337 the recipients' macrophages, we observed that a higher percentage of WAT-C2D cells expressed

338 F4/80 compared to the recipient's macrophages (CFDA negative cells; Figure 4B). We detected

339 no significant differences in the \% positive cells that expressed Ly-6C, Mac-2 or CD11b when

340 we compared WAT-C2D and recipient macrophages (Figure 4B).

341 To further characterize the impact of the adipose microenvironment on recently migrated

342 macrophages, we measured transcript levels in C2D macrophages that were isolated and sorted

343 from the peritoneal cavity, WAT or BAT. We measured the expression of an array of

344 inflammatory chemokines and cytokines and their receptor genes by quantitative PCR. As 
345 shown in Figure 5, the overall expression of chemokine, cytokine and receptor genes was

346 dramatically down-regulated in BAT-C2D cells relative to the gene expression of C2D cells

347 maintained in vitro, compared to those of PEC-C2D and/or sorted WAT-C2D cells. When

348 WAT-C2D cells were compared to PEC-C2D macrophage cells, transcript levels for several

349 chemokines were lower (Figure 5A). These included MIP-3b/CCL19 (3 vs. 9 fold), NAP-

350 3/CXCL1 (-0.5 vs. 5 fold), CCL11 (1 vs. 6 fold), CXCL5 (2 vs. 4 fold), CXCL9 (3 vs. 7) and

351 CXCL12 (4 vs. 12 fold). MIP-1a/CCL3 and MCP-5/CCL12 were also down-regulated in PEC-

352 C2D compared to C2D macrophages grown in vitro.

353 Interestingly we found that two cytokines receptor genes had higher transcript levels in

354 PEC-C2D macrophage cells compared to WAT-C2D macrophage cells; CD121a/IL 1r1 (8 vs. 2

355 fold) and CD130/IL6st (6 vs. 3 fold). Additionally, C3 (5 vs.1 fold) had higher expression in

356 PEC-C2D cells compared to WAT C2D cells (Figure 5E).

357 3.3 Macrophages gene expression in response to WAT and BAT in vitro

358 C2D macrophage cells exhibited distinct phenotypes in response to WAT or BAT

359 adipose environments. Therefore, to confirm that C2D macrophage behavior reflected that of

360 primary macrophages, we indirectly co-cultured BM-Mo in transwell plates (top) with

361 collagenase-digested WAT and BAT (bottom). RNA from the BM-Mo was isolated and the

362 transcript levels of $T N F-\alpha, I L-6, I L-1 \beta$, Arg-1, Ym-1 and Fizz-1 were assessed using qRT-PCR

363 (Table 1). WAT incubated BM-Mo macrophages had higher TNF- $\alpha$ and $I L-6$ transcript levels

364 than BAT-BM Mo (Table 1). This would be consistent with the observations seen with C2D

365 macrophages. In contrast, there were no differences in $I L-1 \beta$ or the anti inflammatory genes

366 Arg-1, Ym-1 and Fizz-1 between BM-Mo inoculated in WAT or BAT (Table 1). 


\section{Discussion}

Adipose tissue contains a heterogeneous array of cells including preadipocytes and

370 adipocytes along with resident and inflammatory macrophages constituting up to 40 percent of

371 the cell population [34]. Additionally, the trafficking of C2D macrophage cells to both WAT

372 and BAT provided a unique opportunity to determine the impact of these distinct adipose

373 environments on recently immigrating macrophages and how different microenvironments affect

374 macrophage plasticity. We used the C2D macrophage cell line to investigate this question. This

375 is a powerful model because the cells are phenotypically defined both in vitro and in vivo and the

376 phenotypic change of the C2D macrophages in response to WAT or BAT paralleled the in vitro

377 response of primary macrophages $\{$ Table 1; also see reference [35] $\}$. Therefore, by knowing the

378 characteristics of the C2D macrophages before and after exposure to the different adipose tissues

379 we know exactly what changes are due to their immediate exposure to different

380 microenvironments. Indeed, the finding that preadipocytes allowed C2D macrophage cells to

381 spread regardless of their differentiation state, while white adipocytes inhibited macrophage

382 spreading supports the hypothesis that macrophage phenotype is dependent on the adipose tissue

383 microenvironment.

384 WAT has been well characterized. There are differences in $\mathrm{CD}^{+} 8^{+}$macrophages between

385 visceral and subcutaneous WAT [36]. “Obese” WAT has increased proinflammatory cytokine

386 transcripts [37,38] and secreted cytokines such as TNF [39], angiotensinogen, PAI-1,

387 PGAR/FIAF, IL-6, leptin, and resistin [40-42]. In particular, isolated adipocytes secrete TNF-

388 alpha, IL-6, IL-8, IL-1Ra, IL-10, leptin, adiponectin, resistin [41] and visfatin [40,43] and

389 various populations of $\mathrm{CD}_{14}{ }^{+} \mathrm{CD} 31^{+}$adipose tissue macrophages (ATMs) [40] or MGL1 ${ }^{+}$

390 ATMs have increased IL10, Arg1, and Pgclb transcript levels [44] or secrete MCP-1, MIP-1 $\alpha$ 
391 and IL-8 [43]. Nos2 and $I L 1 b$ transcripts also go up in MGL1' CCR2 ${ }^{+}$macrophage populations

392 around necrotic adipocytes [44]. One explanation for the differences may be the origins of the

393 tissues. Brown adipose cells may be more closely related to muscle cells than white adipose

394 cells [45,46]. Macrophages in normal muscle are angiogenic or anti-inflammatory [47]. In

395 addition, BAT and WAT express and secrete different autocrine, paracrine and endocrine

396 signals. WAT has been recognized as an endocrine organ. It produces and secretes a plethoric

397 collection of adipokines [48-50]. Among them for example, adipsin, leptin and adiponectin are

398 highly expressed in WAT, whereas their production in BAT is associated only with

399 thermogenically inactive BAT cells [51]. In contrast, BAT has been reported to express other

400 cellular mediators, such as basic fibroblast growth factor [52] and prostaglandins E2 and F2 $\alpha$

401 [53]. BAT cells also produce T4 thyroxine deiodinase type II [54] and nitric oxide synthase

402 enzymes (eNOS and iNOS) [55] which enables it to produce T3 and NO, respectively.

403 Uncoupling protein, unique to BAT, also exhibits chloride channel properties [56]. Chloride

404 channels can regulate NADPH oxidase membrane depolarization [57] and can regulate

405 phagocyte cell function [58]. Therefore, it is possible that BAT can regulate the C2D

406 macrophage cell phenotype because of UCP's unique ability to regulate oxidative metabolism.

407 While it is not clear at present what specific molecular mechanisms are responsible for the

408 distinct phenotypic differences between WAT-C2D and BAT-C2D, we have shown that there are

409 significant interactions between adipocytes and macrophages that is mediated by cytokines and

410 cell-cell contact that affects the differentiation and function of both macrophages and adipocytes

411 [35]. This current study extends the macrophage interaction to include brown adipocytes by

412 showing that $\mathrm{C} 2 \mathrm{D}$ macrophages traffic to the BAT and they acquire a phenotype unique to that 
413 tissue. The data support the hypothesis that macrophage plasticity is dependent upon

414 environmental signals and is not predetermined as some have suggested [10].

It is possible that the adoptive transfer technique or procedures used in recovering

417 macrophages for our study may have impacted the results. First, adoptive transfer could have

418 induced a peritonitis or inflammation in the adipose tissue. We do not believe this to be the case.

419 Although, we detected some neutrophils (28\% PMNs in PEC, 3\% in BAT and 10\% in WAT), the

420 lack of an acute inflammatory response where one would expect a large PMN inflammation

421 (>80\% PMN) [59] and extensive macrophage activation [60] suggests that we did not induce a

422 peritonitis or abnormal inflammation in these tissues. We found that the recipient host

423 macrophages that were isolated from the SVF had a similar cell surface phenotype to the WAT-

424 C2D cells. These data suggest that the C2D macrophages were acquiring a "resident

425 macrophage phenotype" as opposed to a proinflammatory phenotype which would be expected

426 of recently immigrating macrophages in obese mice $[18,43]$. This hypothesis is supported by

427 the fact that we saw inconsistent evidence of a proinflammatory phenotype in WAT-C2D

428 because both M1 (e.g. TNF- $\alpha$ ) and M2 (IL-10) [61,62] markers were up regulated. The

429 differential counts of the cells in WAT and BAT also did not reflect an inflammatory milieu.

430 The CD11b expression on WAT-C2D macrophages would also be reflective of cells which are

431 undergoing normal cell trafficking [63].

432 Ruan et al. found that the isolation of adipocytes with collagenase for 2 hours led to the

433 activation of the adipocytes when they were assayed in vitro [64]. Our macrophages were

434 isolated with a 40 minute collagenase treatment and that exposure could have affected them and

435 we cannot rule out this possibility. However, the adipocytes were separated from the 
macrophages quickly and the expression of some of the genes of interest (e.g. TNF and TNFR)

437 take several hours to upregulate [64]. In addition, if collagenase had a general activating action 438 on the C2D macrophage cells [65], we probably would not have seen the general down

439 regulation of $\mathrm{C} 2 \mathrm{D}$ macrophage cell gene transcripts in BAT unless BAT had a suppressive 440 environment.

441 Lastly, we were concerned that the $16 \mathrm{~h}$ incubation that we included before we assessed 442 surface marker expression could have affected the macrophage phenotype [66]. We see changes 443 in C2D macrophages when they are reintroduced to in vitro culture. However, two observations 444 suggest that the cell surface expressions we report are an accurate sampling of the C2D

445 macrophage phenotype. 1) The changes induced in vivo were still evident after an additional 16

446 hours of in vitro culture and 2) the differential expression of surface markers such as CD11b in

447 BAT and WAT paralleled the general changes in transcript level in those same tissues. The

448 RNA used for those analyses was not subject to the $16 \mathrm{~h}$. incubations.

449 In summary, the WAT microenvironment altered C2D macrophage cells differently than

450 BAT. The changes in WAT were dependent upon the differentiation of both the macrophages

451 and the adipocytes. In addition, WAT caused C2D macrophage cells to upregulate many genes

452 and molecules compared to when they were isolated from BAT. To our knowledge, this is the

453 first study to directly compare the macrophages that have recently trafficked to different adipose

454 tissues in the absence of complicating chronic diseases or altered genetic states. The evidence

455 that infiltrating macrophages begin to display unique tissue-specific phenotypes in normal mice

456 reaffirms the adaptive nature of macrophages to their environment. Determining the properties

457 of adipose tissue that make BAT and WAT so different may give us clues on how to regulate

458 macrophages to prevent disease.

459 


\section{Acknowledgements}

461 We thank Ms. Tammy Koopman for her assistance with flow cytometry, Dr. Dan Boyle 462 for his help with confocal microscopy, and Dr. Kurt Zhang for his help with statistical analysis. 463 We thank Ms. Alison Luce-Fedrow for her laboratory assistance and Ms. Lea Dib for her input 464 and review of the manuscript. This project has been supported by American Heart Association 465 grant 0950036G, NIH grants AI55052, AI052206, AI088070, RR16475, RR17686, RR17708, 466 NASA grants NAG2-1274 and NNX08BA91G, European Commission (Grant HEALTH-F4467 2008-223450), funding from Diabetes UK and the Wellcome Trust, the Kansas Agriculture 468 Experiment station and the Terry C. Johnson Center for Basic Cancer Research. This is Kansas 469 Agriculture Experiment Station publication 09-132-J. 


\section{References}

472

473

474

475

476

477

478

479

480

481

482

483

484

485

486

487

488

489

490

491

492

493

494

495

496

497

498

499

500

501

502

503

504

505

506

507

508

509

510

511

512

513

514

515

[1] M. Meltzer, M. Occhionero, and L. Ruco, Macrophage activation for tumor cytotoxicity: Regulatory mechanisms for induction and control of cytotoxic activity. Fed. Proc. 41 (1982) 2198-2205.

[2] L. Ruco, and M. Meltzer, Macrophage activation for tumor cytotoxicity: Induction of tumoricidal macrophages by supernatants of PPD-stimulated Bacillus Calmette-Guerinimmune spleen cell cultures. J. Immunol. 119 (1977) 889-896.

[3] W. Wiktor-Jedrzejczak, B. Dzwigala, M. Szperl, M. Maruszynski, E. Urbanowska, and P. Szwech, Colony-stimulation factor 1-dependent resident macrophages play a regulatory role in fighting Escherichia coli fecal peritonitis. Infect. Immun. 64 (1996) 1577-1581.

[4] T.K. Held, X. Weihua, L. Yuan, D.V. Kalvakolanu, and A.S. Cross, Gamma interferon augments macrophage activation by lipopolysaccharide by two distinct mechanisms, at the signal transduction level and via an autocrine mechanism involving tumor necrosis factor alpha and interleukin-1. Infect Immun 67 (1999) 206-12.

[5] M. Dorger, S. Munzing, A.M. Allmeling, K. Messmer, and F. Krombach, Phenotypic and functional differences between rat alveolar, pleural, and peritoneal macrophages. Exp Lung Res 27 (2001) 65-76.

[6] J.F. Cailhier, M. Partolina, S. Vuthoori, S. Wu, K. Ko, S. Watson, J. Savill, J. Hughes, and R.A. Lang, Conditional macrophage ablation demonstrates that resident macrophages initiate acute peritoneal inflammation. J Immunol 174 (2005) 2336-42.

[7] K. Takahashi, M. Naito, and M. Takeya, Development and heterogeneity of macrophages and their related cells through their differentiation pathways. Pathol Int 46 (1996) 473-85.

[8] M. Naito, S. Umeda, T. Yamamoto, H. Moriyama, H. Umezu, G. Hasegawa, H. Usuda, L. Shultz, and K. Takahashi, Development, differentiation, and phenotypic heterogeneity of murine tissue macrophages. J Leukoc Biol 59 (1996) 133-138.

[9] S. Gordon, and P.R. Taylor, Monocyte and macrophage heterogeneity. Nat Rev Immunol 5 (2005) 953-64.

[10] F. Geissmann, M.G. Manz, S. Jung, M.H. Sieweke, M. Merad, and K. Ley, Development of monocytes, macrophages, and dendritic cells. Science 327 (2010) 656-61.

[11] M.S. Rutherford, A. Witsell, and L.B. Schook, Mechanisms generating functionally heterogeneous macrophages: chaos revisited. J Leukoc Biol 53 (1993) 602-18.

[12] D.L. Laskin, B. Weinberger, and J.D. Laskin, Functional heterogeneity in liver and lung macrophages. J Leukoc Biol 70 (2001) 163-70.

[13] R.D. Stout, and J. Suttles, Functional plasticity of macrophages: reversible adaptation to changing microenvironments. J Leukoc Biol 76 (2004) 509-13.

[14] F. Geissmann, S. Jung, and D.R. Littman, Blood monocytes consist of two principal subsets with distinct migratory properties. Immunity 19 (2003) 71-82.

[15] B.E. Potts, M.L. Hart, L.L. Snyder, D. Boyle, D.A. Mosier, and S.K. Chapes, Differentiation of C2D macrophage cells after adoptive transfer. Clin Vaccine Immunol 15 (2008) 243-252.

[16] B.E. Potts, and S.K. Chapes, Functions of C2D macrophage cells after adoptive transfer. J Leukoc Biol 83 (2008) 602-609.

[17] J.N. Fain, A.K. Madan, M.L. Hiler, P. Cheema, and S.W. Bahouth, Comparison of the release of adipokines by adipose tissue, adipose tissue matrix, and adipocytes from 
visceral and subcutaneous abdominal adipose tissues of obese humans. Endocrinology 145 (2004) 2273-82.

[18] G. Fantuzzi, Adipose tissue, adipokines, and inflammation. J Allergy Clin Immunol 115 (2005) 911-9; quiz 920.

[19] S. Klaus, Functional differentiation of white and brown adipocytes. Bioessays 19 (1997) 215-23.

[20] K. Adachi, M. Miki, H. Tamai, M. Tokuda, and M. Mino, Adipose tissues and vitamin E. J Nutr Sci Vitaminol (Tokyo) 36 (1990) 327-37.

[21] J. Himms-Hagen, Brown adipose tissue thermogenesis: interdisciplinary studies. Faseb J 4 (1990) 2890-8.

[22] J. Nedergaard, T. Bengtsson, and B. Cannon, Unexpected evidence for active brown adipose tissue in adult humans. Am J Physiol Endocrinol Metab 293 (2007) E444-52.

[23] K.A. Virtanen, M.E. Lidell, J. Orava, M. Heglind, R. Westergren, T. Niemi, M. Taittonen, J. Laine, N.J. Savisto, S. Enerback, and P. Nuutila, Functional brown adipose tissue in healthy adults. N Engl J Med 360 (2009) 1518-25.

[24] P. Lee, J.R. Greenfield, K.K. Ho, and M.J. Fulham, A critical appraisal of prevalence and metabolic significance of brown adipose tissue in adult humans. Am J Physiol Endocrinol Metab (2010).

[25] J.A. Villena, B. Cousin, L. Penicaud, and L. Casteilla, Adipose tissues display differential phagocytic and microbicidal activities depending on their localization. Int J Obes Relat Metab Disord 25 (2001) 1275-80.

[26] A.A. Beharka, J.W. Armstrong, and S.K. Chapes, Macrophage cell lines derived from major histocompatibility complex II-negative mice. In Vitro Cell. Dev. Biol. 34 (1998) 499507.

[27] L. Xie, D. Boyle, D. Sanford, P.E. Scherer, J.E. Pessin, and S. Mora, Intracellular trafficking and secretion of adiponectin is dependent on GGA-coated vesicles. J Biol Chem 281 (2006) 7253-9.

[28] M. Rodbell, Localization of Lipoprotein Lipase in Fat Cells of Rat Adipose Tissue. J Biol Chem 239 (1964) 753-5.

[29] M. Rodbell, Metabolism of Isolated Fat Cells. I. Effects of Hormones on Glucose Metabolism and Lipolysis. J Biol Chem 239 (1964) 375-80.

[30] P. Seale, S. Kajimura, W. Yang, S. Chin, L.M. Rohas, M. Uldry, G. Tavernier, D. Langin, and B.M. Spiegelman, Transcriptional control of brown fat determination by PRDM16. Cell Metab 6 (2007) 38-54.

[31] M. Murholm, K. Dixen, K. Qvortrup, L.H. Hansen, E.Z. Amri, L. Madsen, G. Barbatelli, B. Quistorff, and J.B. Hansen, Dynamic regulation of genes involved in mitochondrial DNA replication and transcription during mouse brown fat cell differentiation and recruitment. PLoS One 4 (2009) e8458.

[32] M.W. Pfaffl, A new mathematical model for relative quantification in real-time RT-PCR. Nucleic Acids Res 29 (2001) e45.

[33] B.M. Phillips, J.W. Hunt, B.S. Anderson, H.M. Puckett, R. Fairey, C.J. Wilson, and R. Tjeerdema, Statistical significance of sediment toxicity test results: threshold values derived by the detectable significance approach. Environ Toxicol Chem 20 (2001) 371-3. [34] J.G. Neels, and J.M. Olefsky, Inflamed fat: what starts the fire? J Clin Invest 116 (2006) 335. 
[35] L. Xie, M.T. Ortega, S. Mora, and S.K. Chapes, Interactive changes between macrophages and adipocytes. Clin Vaccine Immunol 17 (2010) 651-9.

[36] A. Bouloumie, C.A. Curat, C. Sengenes, K. Lolmede, A. Miranville, and R. Busse, Role of macrophage tissue infiltration in metabolic diseases. Curr Opin Clin Nutr Metab Care 8 (2005) 347-54.

[37] G. Hotamisligil, N. Shargill, and B. Spiegelman, Adipose expression of tumor necrosis factor-alpha: Direct role in obesity-linked insulin resistance. Science 259 (1993) 87-91.

[38] V. Rotter, I. Nagaev, and U. Smith, Interleukin-6 (IL-6) induces insulin resistance in 3T3L1 adipocytes and is, like IL-8 and tumor necrosis factor-alpha, overexpressed in human fat cells from insulin-resistant subjects. J Biol Chem 278 (2003) 45777-84.

[39] R. Cancello, J. Tordjman, C. Poitou, G. Guilhem, J.L. Bouillot, D. Hugol, C. Coussieu, A. Basdevant, A. Bar Hen, P. Bedossa, M. Guerre-Millo, and K. Clement, Increased infiltration of macrophages in omental adipose tissue is associated with marked hepatic lesions in morbid human obesity. Diabetes 55 (2006) 1554-61.

[40] G. Fantuzzi, Adipose tissue, adipokines, and inflammation. J Allergy Clin Immunol 115 (2005) 911-9.

[41] M. Guerre-Millo, Adipose tissue hormones. J Endocrinol Invest 25 (2002) 855-61.

[42] H. Ruan, and H.F. Lodish, Insulin resistance in adipose tissue: direct and indirect effects of tumor necrosis factor-alpha. Cytokine Growth Factor Rev 14 (2003) 447-55.

[43] C.N. Lumeng, J.B. DelProposto, D.J. Westcott, and A.R. Saltiel, Phenotypic switching of adipose tissue macrophages with obesity is generated by spatiotemporal differences in macrophage subtypes. Diabetes 57 (2008) 3239-46.

[44] T.J. Guzik, D. Mangalat, and R. Korbut, Adipocytokines - novel link between inflammation and vascular function? J Physiol Pharmacol 57 (2006) 505-28.

[45] Y.H. Tseng, E. Kokkotou, T.J. Schulz, T.L. Huang, J.N. Winnay, C.M. Taniguchi, T.T. Tran, R. Suzuki, D.O. Espinoza, Y. Yamamoto, M.J. Ahrens, A.T. Dudley, A.W. Norris, R.N. Kulkarni, and C.R. Kahn, New role of bone morphogenetic protein 7 in brown adipogenesis and energy expenditure. Nature 454 (2008) 1000-4.

[46] P. Seale, B. Bjork, W. Yang, S. Kajimura, S. Chin, S. Kuang, A. Scime, S. Devarakonda, H.M. Conroe, H. Erdjument-Bromage, P. Tempst, M.A. Rudnicki, D.R. Beier, and B.M. Spiegelman, PRDM16 controls a brown fat/skeletal muscle switch. Nature 454 (2008) 961-7.

[47] L. Arnold, A. Henry, F. Poron, Y. Baba-Amer, N. van Rooijen, A. Plonquet, R.K. Gherardi, and B. Chazaud, Inflammatory monocytes recruited after skeletal muscle injury switch into antiinflammatory macrophages to support myogenesis. J. Exp. Med. 204 (2007) 1057-1069.

[48] R.S. Ahima, and J.S. Flier, Adipose tissue as an endocrine organ. Trends Endocrinol Metab 11 (2000) 327-32.

[49] E. Maury, and S.M. Brichard, Adipokine dysregulation, adipose tissue inflammation and metabolic syndrome. Mol Cell Endocrinol (2009).

[50] S.E. Wozniak, L.L. Gee, M.S. Wachtel, and E.E. Frezza, Adipose tissue: the new endocrine organ? A review article. Dig Dis Sci 54 (2009) 1847-56.

[51] B. Cannon, and J. Nedergaard, Brown adipose tissue: function and physiological significance. Physiol Rev 84 (2004) 277-359.

[52] A. Asano, K. Kimura, and M. Saito, Cold-induced mRNA expression of angiogenic factors in rat brown adipose tissue. J Vet Med Sci 61 (1999) 403-9. 
[53] R. Portet, F. de Marco, L. Zizine, R. Bertin, and C. Senault, Perinatal variations of prostaglandins $\mathrm{E} 2$ and $\mathrm{F}$ alpha levels in brown adipose tissue of the rat; effects of ambient temperature. Biochimie 62 (1980) 715-8.

[54] J.E. Silva, and P.R. Larsen, Adrenergic activation of triiodothyronine production in brown adipose tissue. Nature 305 (1983) 712-3.

[55] K. Kikuchi-Utsumi, B. Gao, H. Ohinata, M. Hashimoto, N. Yamamoto, and A. Kuroshima, Enhanced gene expression of endothelial nitric oxide synthase in brown adipose tissue during cold exposure. Am J Physiol Regul Integr Comp Physiol 282 (2002) R623-6.

[56] S.G. Huang, and M. Klingenberg, Chloride channel properties of the uncoupling protein from brown adipose tissue mitochondria: a patch-clamp study. Biochemistry 35 (1996) 16806-14.

[57] J. Ahluwalia, Chloride channels activated by swell can regulate the NADPH oxidase generated membrane depolarisation in activated human neutrophils. Biochem Biophys Res Commun 365 (2008) 328-33.

[58] J.G. Moreland, A.P. Davis, G. Bailey, W.M. Nauseef, and F.S. Lamb, Anion channels, including ClC-3, are required for normal neutrophil oxidative function, phagocytosis, and transendothelial migration. J Biol Chem 281 (2006) 12277-88.

[59] S.K. Chapes, and S. Haskill, Evidence for granulocyte-mediated macrophage activation after C. parvum immunization. Cell. Immunol. 75 (1983) 367-377.

[60] E. Knudsen, P.O. Iversen, N. Van Rooijen, and H.B. Benestad, Macrophage-dependent regulation of neutrophil mobilization and chemotaxis during development of sterile peritonitis in the rat. Eur J Haematol 69 (2002) 284-96.

[61] M. Munder, K. Eichmann, and M. Modolell, Alternative metabolic states in murine macrophages reflected by the nitric oxide synthase/arginase balance: competitive regulation by CD4+ T cells correlates with Th1/Th2 phenotype. J Immunol 160 (1998) 5347-54.

[62] J.P. Edwards, X. Zhang, K.A. Frauwirth, and D.M. Mosser, Biochemical and functional characterization of three activated macrophage populations, 2006, pp. 1298-1307.

[63] H.E. Broxmeyer, S. Cooper, G. Hangoc, J.L. Gao, and P.M. Murphy, Dominant myelopoietic effector functions mediated by chemokine receptor CCR1. J Exp Med 189 (1999) 1987-92.

[64] H. Ruan, M.J. Zarnowski, S.W. Cushman, and H.F. Lodish, Standard Isolation of Primary Adipose Cells from Mouse Epididymal Fat Pads Induces Inflammatory Mediators and Down-regulates Adipocyte Genes. J. Biol. Chem. 278 (2003) 47585-47593.

[65] C. Moore, and J.C. Hutson, Physiological relevance of tumor necrosis factor in mediating macrophage-Leydig cell interactions. Endocrinology 134 (1994) 63-69.

[66] S.K. Watkins, N.K. Egilmez, J. Suttles, and R.D. Stout, IL-12 Rapidly Alters the Functional Profile of Tumor-Associated and Tumor-Infiltrating Macrophages In Vitro and In Vivo. J Immunol 178 (2007) 1357-1362. 
651 Fig. 1. Gating strategies for cell sorting of CFDA-SE positive macrophage cells and effects

653 macrophage cells were sorted based on negative expression of CFDA-SE, B) C2D CFDA-SE

654 macrophage cells were sorted based on positive CFDA-SE expression; C) Example of C2D

$655 \mathrm{CFDA}_{-\mathrm{SE}^{+} \text {cells that were sorted from a mixed cell sample such as C2D CFDA-SE }}^{+}$

656 macrophages (region 2) co-cultured with 3T3L1 adipocytes (region 1); D) PEC-C2D

657 macrophages were treated with isotype control antibody (top) or anti Mac-2 antibody (middle

658 and bottom) then assessed by flow cytometry. Cells were treated with PBS (middle) or

659 collagenase (bottom) for 40 minutes before antibody probing.

661 Fig. 2. Change in C2D macrophage cell morphology during co-cultured with adipocytes or 662 pre-adipocytes in vitro and after infiltration into BAT or WAT in vivo. A) C2D macrophage 663 cells were labeled with CFDA-SE or B) C2D macrophage cells labeled with CFDA-SE and 664 isolated from peritoneal cavity (PEC-C2D) were cultured a) alone or co-cultured with b) 3T3L1 665 pre-adipocytes or c) adipocytes as described in the Materials and Methods. Panels a, b and c; 666 Cells viewed on the fluorescent microscope (Magnification x 200). Panels d, e and f are phase 667 contrast images of cells in a, b and c. C) WAT-C2D and BAT-C2D were collected from mice 668 two days after adoptive transfer. C2 D macrophages, WAT and BAT were processed as 669 described in Materials and Methods. Panels a and c images from the confocal microscope (x 670 100). Panels $b$ and $d$ are phase contrast images of the same fields. 
672 Fig. 3. Phenotype changes of C2D macrophage cells co-cultured with adipocytes or pre-

673 adipocytes in vitro. C2D or PEC-C2D cells labeled with CFDA-SE were cultured alone or co-

674 cultured with 3T3L1 adipocytes or pre-adipocytes andthe cell mixtures were immunostained for

675 flow cytometry as described in Materials and Methods. C2D macrophage cells phenotypes were 676 analyzed within CFDA-SE ${ }^{+}$population. A) C2D macrophage cells grown in vitro were cultured

677 alone, co-cultured with 3T3L1 adipocytes or with pre-adipocytes. B) PEC-C2D macrophage

678 cells were cultured alone, co-cultured with adipocytes or with pre-adipocytes. The data is

679 presented as the mean \pm SEM ( $n=3$ independently collected samples per treatment group).

680 Different letters indicate a significant difference between control, preadipocytes or adipocytes for

681 CD11b (lower case) or Mac-2 (upper case) cell surface proteins. A $P$ value of $<0.05$ was 682 considered significant.

683

684 Figure 4. Phenotype changes in C2D macrophage cells isolated from WAT or BAT in vivo

685 after i.p. adoptive transfer. C2D macrophage cells were isolated from WAT and BAT and

686 immunostained to detect Ly-6C, Mac-2, CD11b and F4/80 by flow cytometry. A) Surface

687 marker expression was assessed on CFDA-SE-positive cells isolated from WAT or BAT. B)

688 Surface marker expression was assessed on CFDA-SE-positive cells (left) or CFDA-SE-negative

689 cells (right) in the stromal vascular fraction isolated from WAT. The data is represented as mean

$690 \pm \operatorname{SEM}(\mathrm{n}=3-6$ independently collected samples per adipose tissue type). Comparisons were

691 done between samples stained for the same surface markers in panels A or B. * indicates a

692 significant difference with a $P$ value of $<0.05$.

693 
694 Fig. 5. Expression analysis of C2D macrophage cells isolated from WAT or BAT. C2D

695 macrophage cells were isolated from BAT and WAT by collagenase treatment as described in

696 Materials and Methods. PEC-C2D (black bars), WAT-C2D (white bars) or BAT-C2D (grey bars)

697 were purified by FACS and gene transcripts were quantified by qRT-PCR as described in the

698 Materials and Methods. The data is presented as the mean \pm SEM ( $n=2$ independent RNA

699 samples; fat pads from 4 mice per pooled sample). Significant differences found between: *

700 PEC-C2D vs. WAT-C2D, PEC-C2D vs. BAT-C2D and WAT-C2D vs. BAT-C2D; † PEC-C2D

$701 v s$. BAT-C2D and WAT-C2D vs. BAT-C2D; § PEC-C2D vs. WAT-C2D and PEC-C2D vs.

702 BAT-C2D; - WAT-C2D vs. BAT-C2D; o PEC-C2D vs. WAT-C2D.

703

704

705

706

707 
$>$ C2D macrophage phenotype change rapidly in response to different microenvironments.

$>$ Macrophage phenotype responses are dependent on the differentiated stages of the macrophages and adipocytes.

$>$ Brown adipose tissue has distinct impact on macrophages compared to white adipose tissue. 

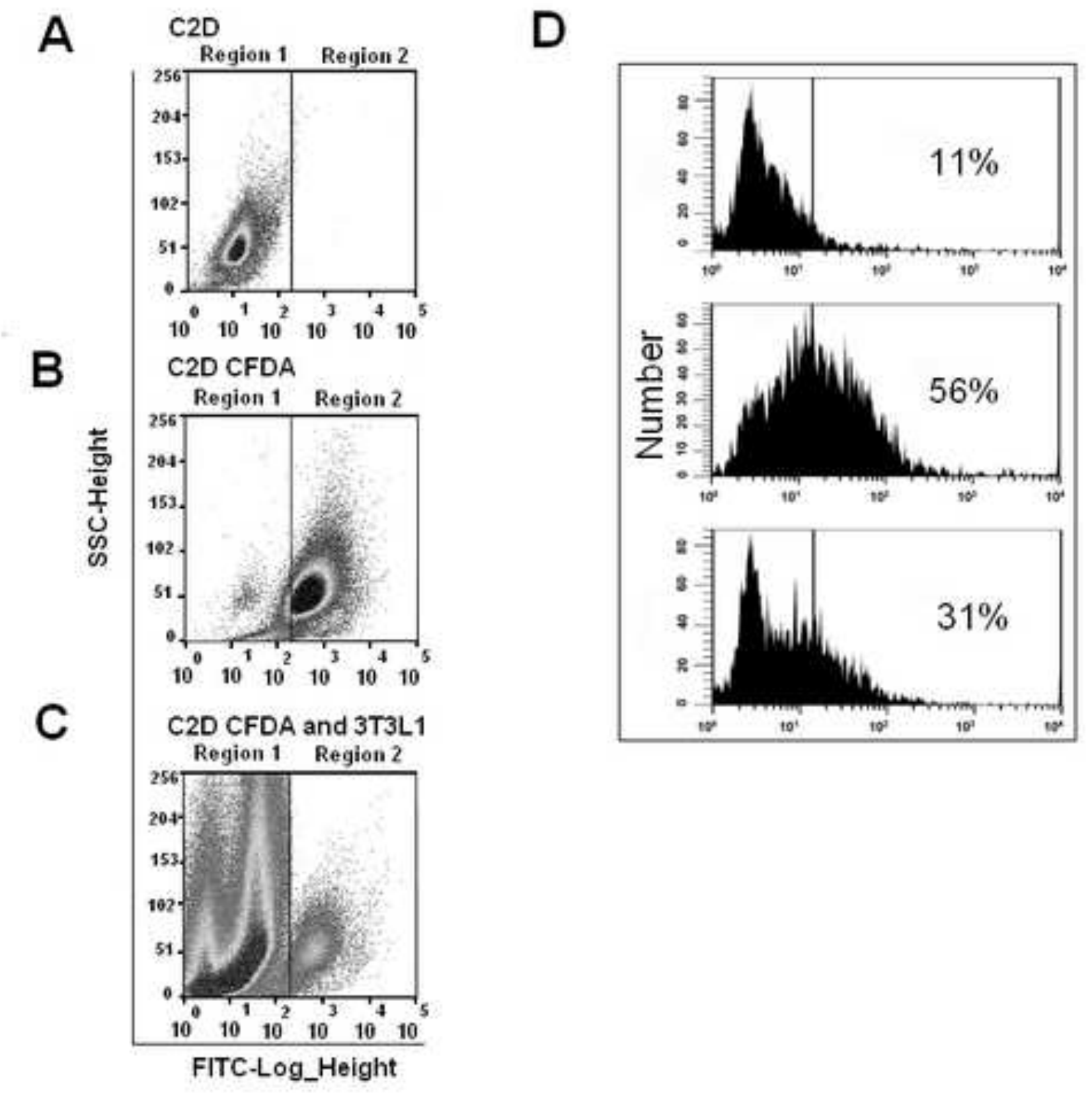

D 
Figure

Click here to download high resolution image

A)
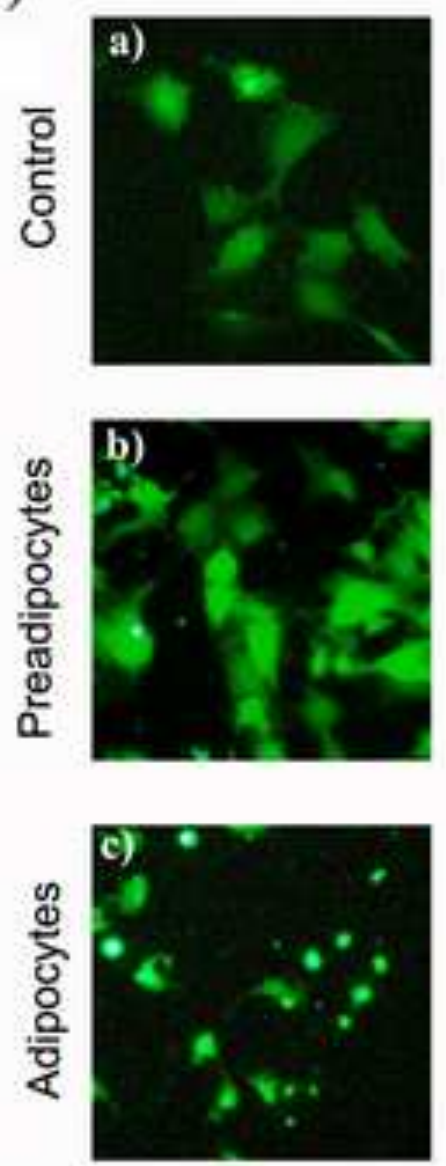

B)
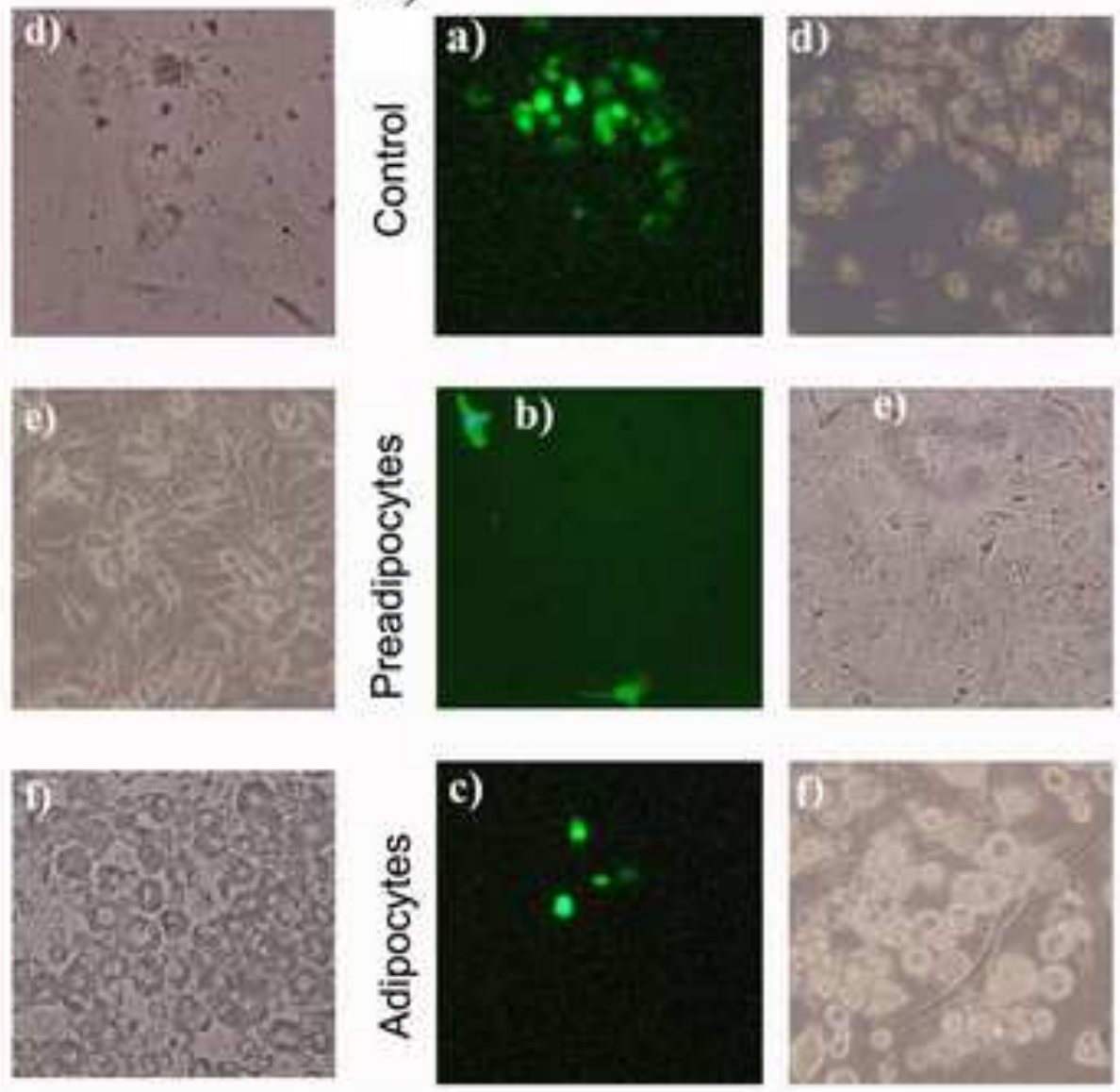

C)

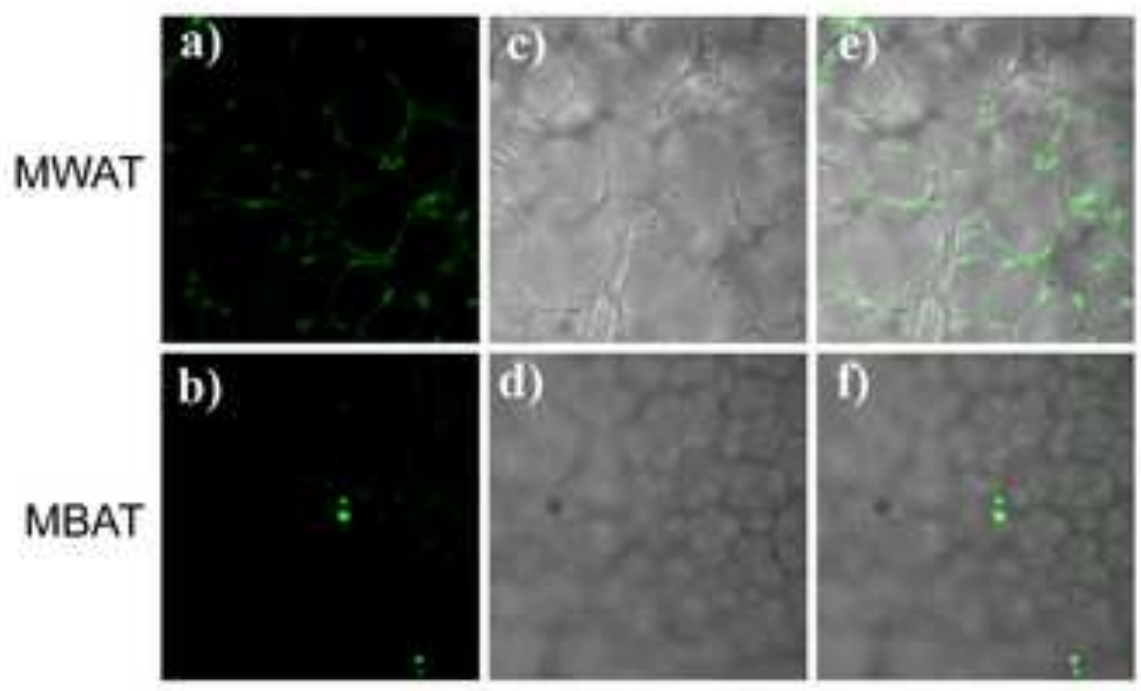


\% Expression on CFDA SE positive cells
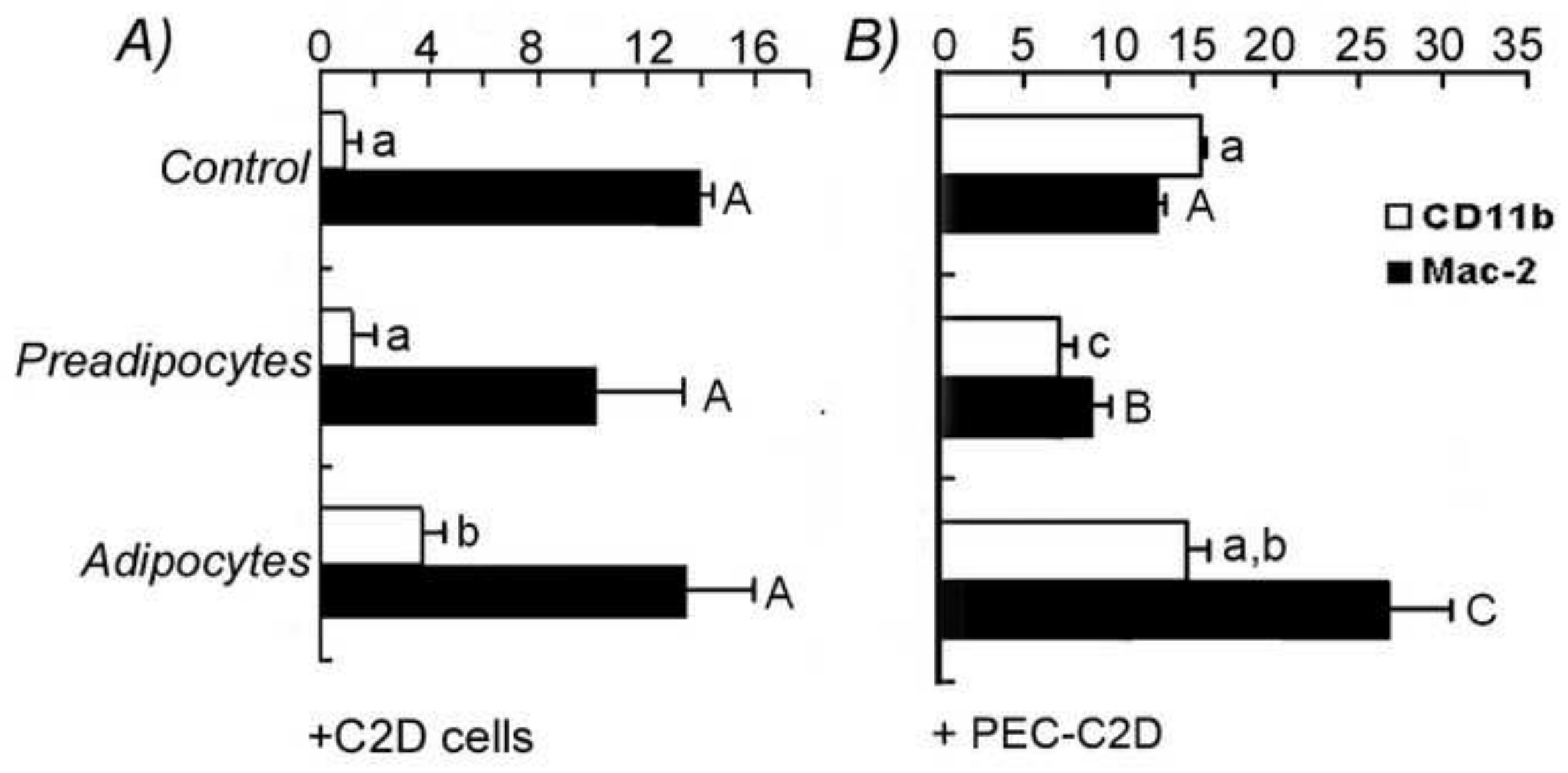
A)

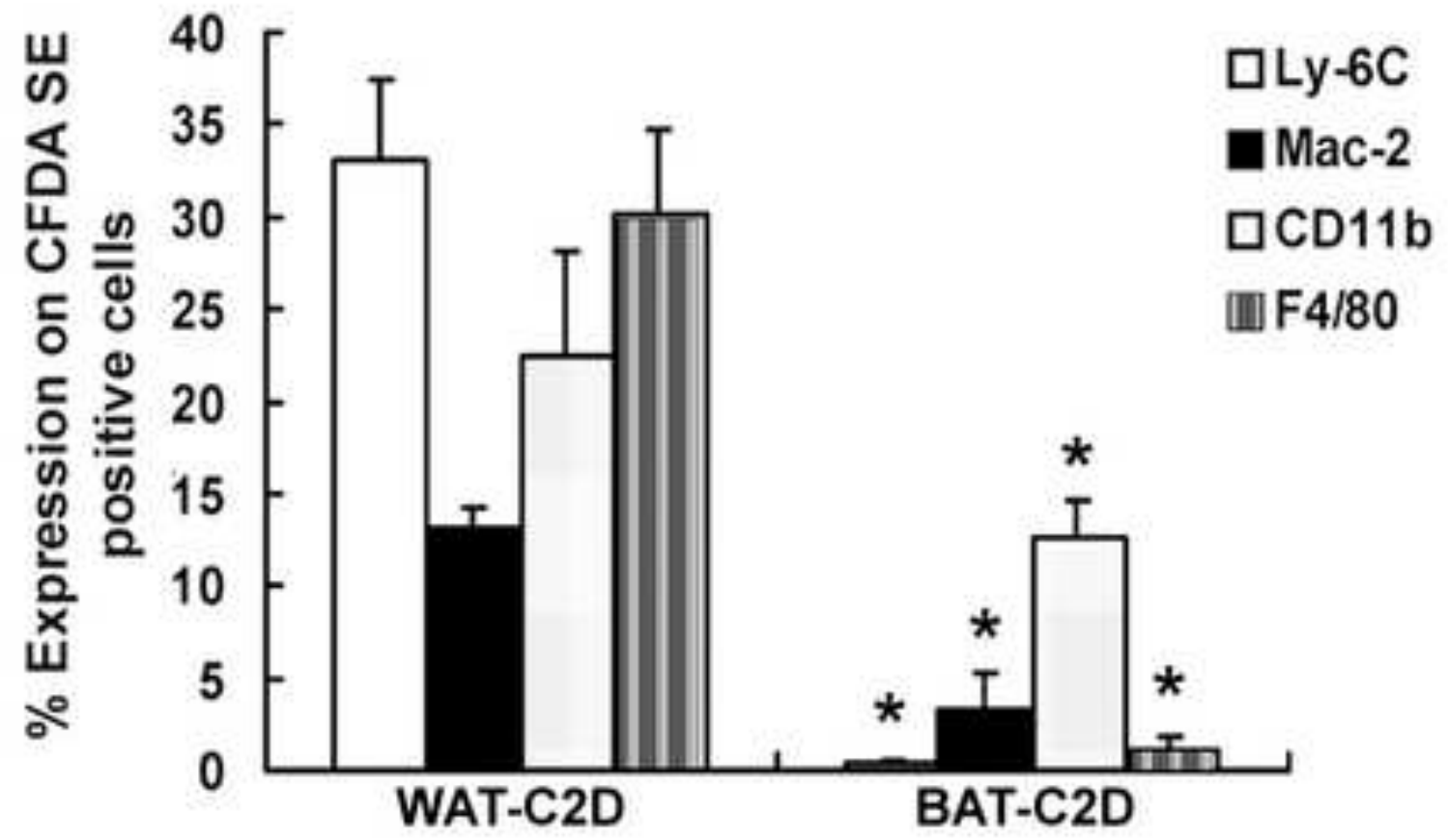

B)

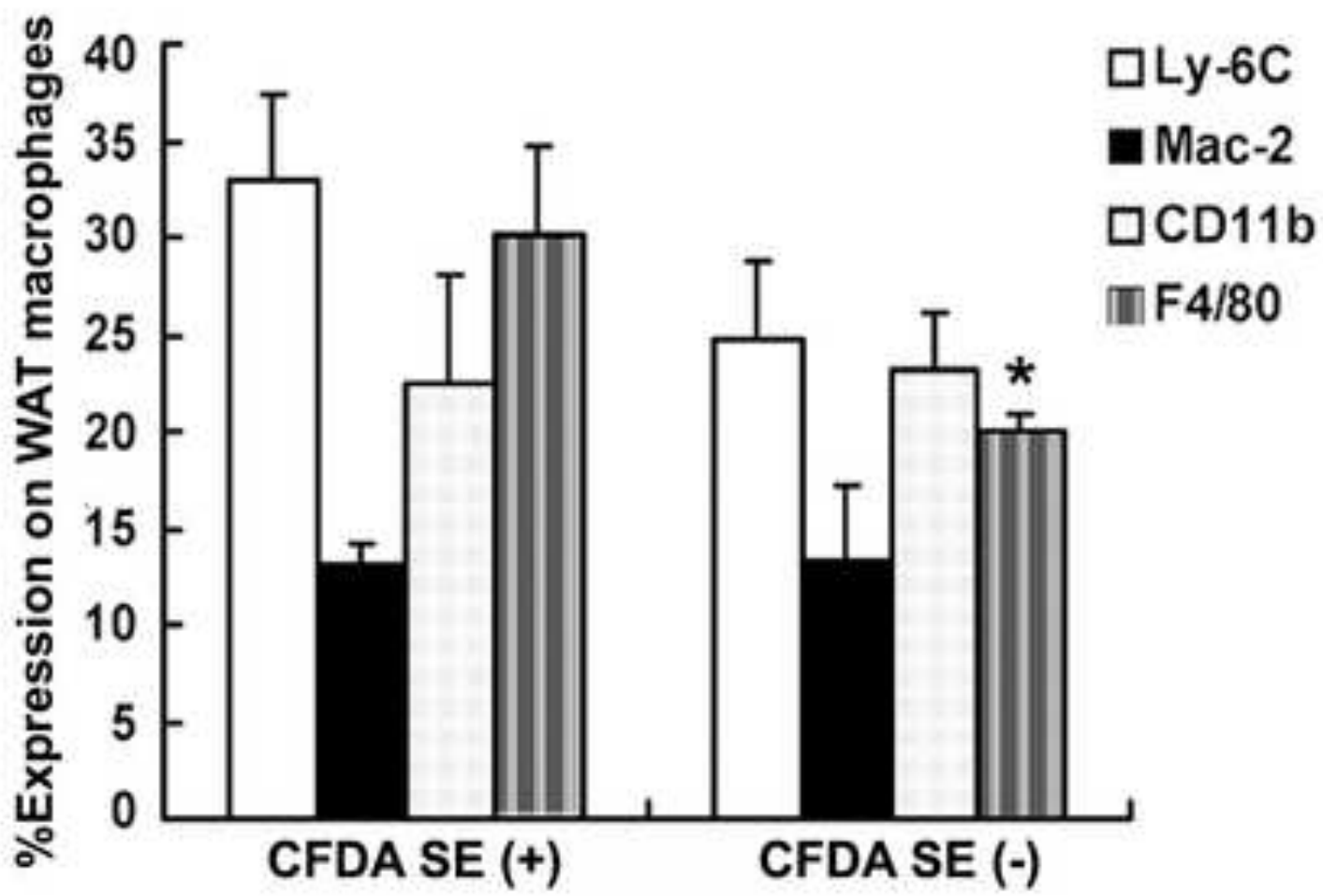


A) Chemokine genes
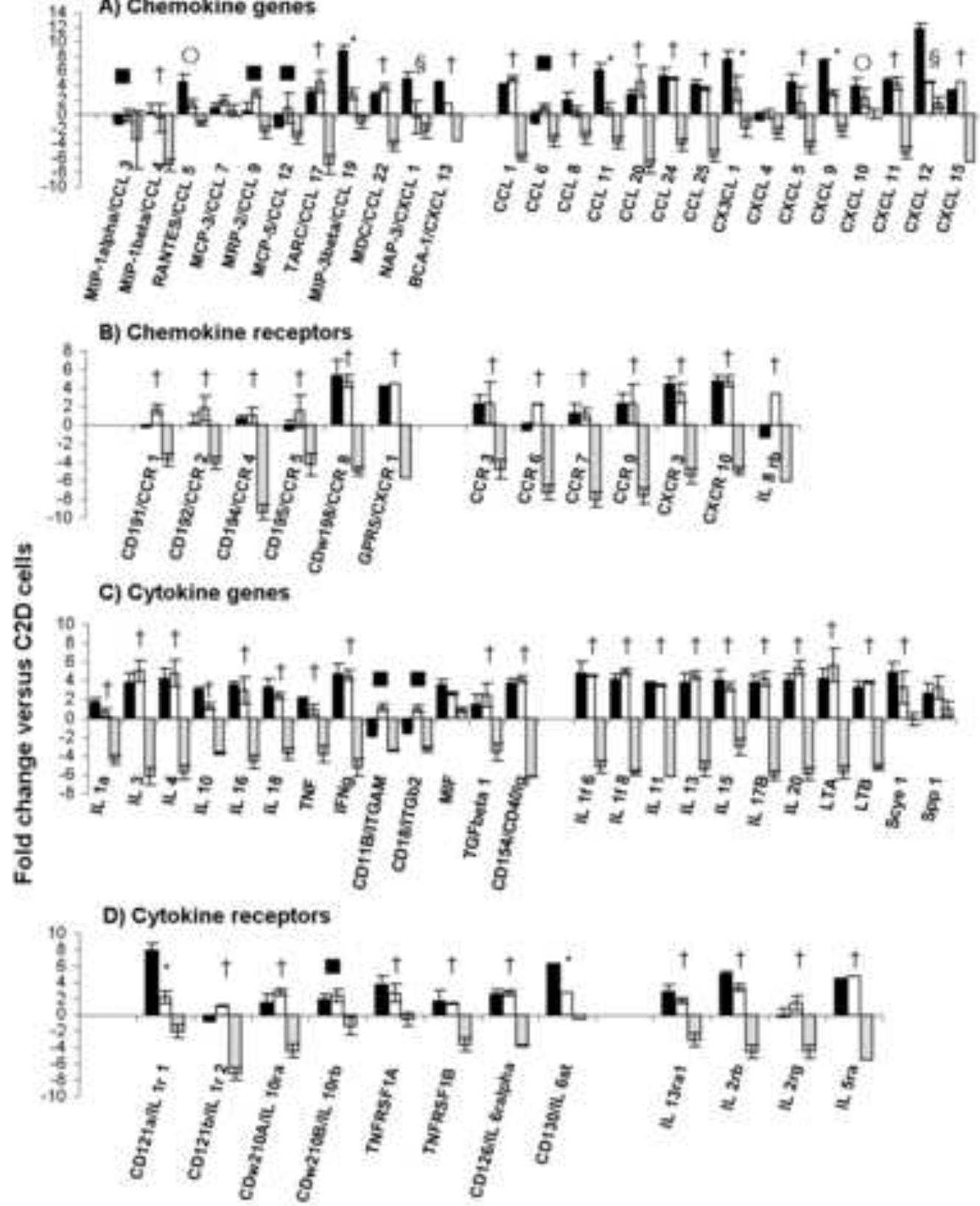

E) Genes involved in inflammatory responses

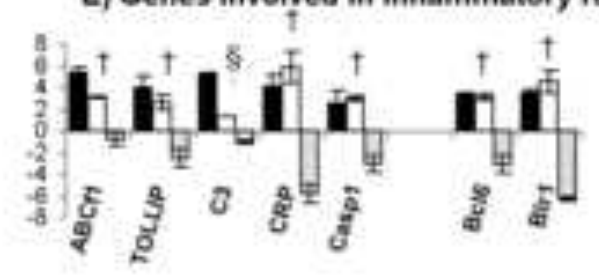


Table 1. Comparison of M1 and M2 gene transcripts in bone marrow derived macrophage cells after $24 \mathrm{~h}$ indirect co-culture with digested adipose tissues.

\begin{tabular}{|l|c|c|}
\hline & \multicolumn{2}{|c|}{$\begin{array}{c}\text { \% gene transcripts compared to bone marrow derived } \\
\text { macrophage cells }\end{array}$} \\
\hline Transcript & BAT-BM Mo $^{1}$ & WAT-BM Mo $^{1}$ \\
\hline$T N F-\alpha$ & $177 \pm 39$ & $370 \pm 46 \dagger$ \\
\hline$I L-6$ & $285 \pm 47$ & $564 \pm 53 \dagger$ \\
\hline$I L-1 \beta$ & $243,871 \pm 154,323$ & $170,380 \pm 29,734$ \\
\hline Arg- 1 & $158 \pm 105$ & $168 \pm 45$ \\
\hline Ym- 1 & $1 \pm 1$ & $5 \pm 3$ \\
\hline Fizz- 1 & $163 \pm 125$ & $212 \pm 35$ \\
\hline
\end{tabular}

1. Bone marrow derived macrophage cells were indirectly co-cultured (plate bottom) with digested fat pads (in transwell insert); WAT-BM Mo bone marrow derived macrophage cells co-cultured with paired gonadal fat pads; BAT-BM Mo bone marrow derived macrophage cells co-cultured with digested perispleen fat.

2. \% gene transcript levels were calculated relative to bone marrow derived macrophages differentiated in vitro as described in the materials and methods.

3. Number represents average \pm standard error of the mean of 3 or 4 independent mouse samples. $\uparrow$ indicates statistical difference compared to BAT-BM Mo, $P<0.05$. 